Portland State University

PDXScholar

Master of Environmental Management Project

Reports

Environmental Science and Management

Spring 2019

Process-Based Modeling of the Dairy McKay

Watershed to Inform Monitoring for Agricultural Best

Management Practices

Brittany Saeman

Portland State University

Follow this and additional works at: https://pdxscholar.library.pdx.edu/mem_gradprojects

Part of the Environmental Health and Protection Commons, Environmental Monitoring Commons, and the Water Resource Management Commons

Let us know how access to this document benefits you.

Recommended Citation

Saeman, Brittany, "Process-Based Modeling of the Dairy McKay Watershed to Inform Monitoring for Agricultural Best Management Practices" (2019). Master of Environmental Management Project Reports. 54.

https://pdxscholar.library.pdx.edu/mem_gradprojects/54

https://doi.org/10.15760/mem.57

This Project is brought to you for free and open access. It has been accepted for inclusion in Master of Environmental Management Project Reports by an authorized administrator of PDXScholar. Please contact us if we can make this document more accessible: pdxscholar@pdx.edu. 


\section{Process-based modeling of the Dairy- McKay Watershed to inform monitoring for agricultural best management practices}

\section{Brittany Saeman}

Report submitted in fulfillment of Professional Science Master (PSM)

Portland State University, Environmental Science and Management In conjunction with Oregon Department of Environmental Quality

Committee Members:

Dr. Joe Maser

Dr. Eugene Foster

Dr. Daniel Sobota
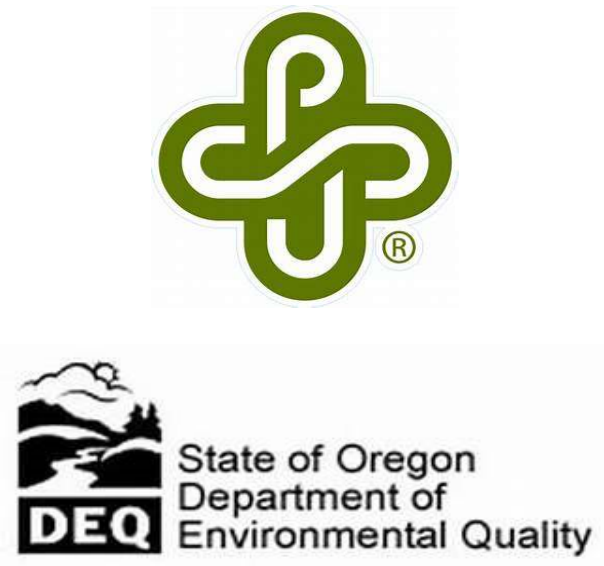


\section{Acknowledgements}

I am grateful to the abundance of individuals that shared their expertise and invested their time in this project. From the Department of Environmental Quality: Dan Sobota, Eugene Foster, Wade Peerman, Maddee Rubinson (no longer at DEQ) and the remaining water quality staff for oversight, assistance and support with various tasks over the project timeline. Dr. Joe Maser, of Portland State University, for his constant availability, advice and support not only with this project, but over my near 3-year progression of receiving my degree. The members/community partners of CEP that aided in my understanding of the Dairy McKay Watershed as well as my data collection efforts, including, but not limited to: Audrey Hatch (OWEB), Ken Fetcho (OWEB), Sheila Marcoe (ODA), Brenda Sanchez (ODA), Michael Merril (NRCS), Dean Moberg (NRCS), Jamie Anthony (ODFW), Lacey Townsend (TSWCD), Aaron Shaw (TSWCD), Mac Martin (CWS) and Laura Porter (CWS). I would also like to thank Jiajia Lin (EPA) for sharing data and Meghna Babbar-Sebens (OSU) for her expertise and assistance in understanding of the SWAT model formatting and application. Without this large list of extraordinary humans, my project would not have been possible.

To my family and friends who constantly encouraged and supported me from near and far, I thank you from the bottom of my heart. I am forever grateful to Luke Contreras for his financial and emotional support over the pursuance of my degree, none of this would be possible without the laughs you fostered in times of stress. This project was partially funded by the Edward and Olive Bushby Scholarship awarded to me by the Department of Environmental Science and Management at Portland State University. 


\section{Table of Contents}

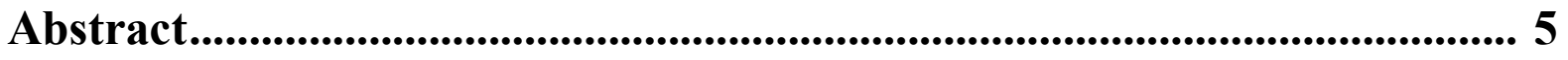

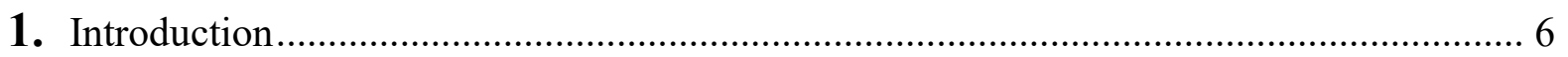

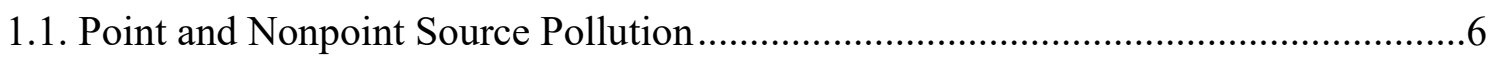

1.2. Watershed Modeling NPS .................................................................................

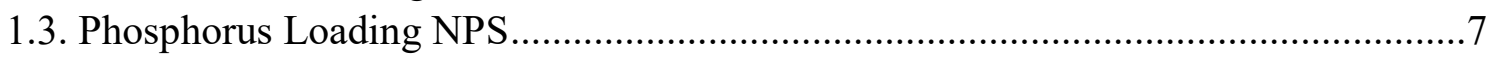

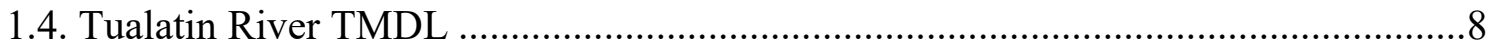

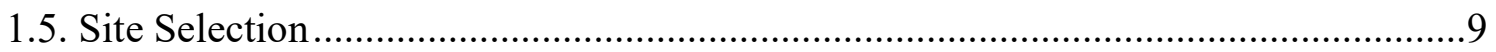

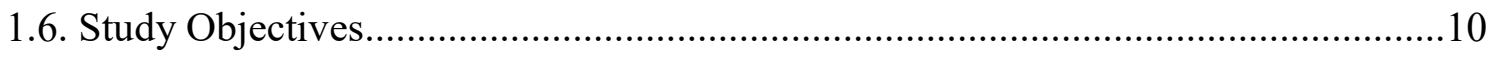

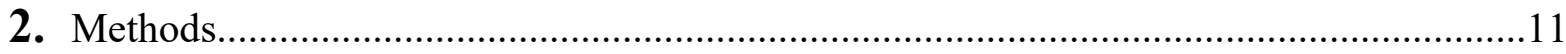

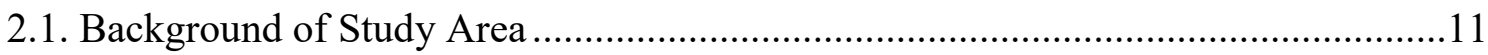

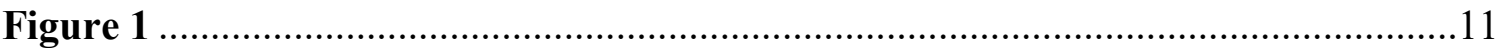

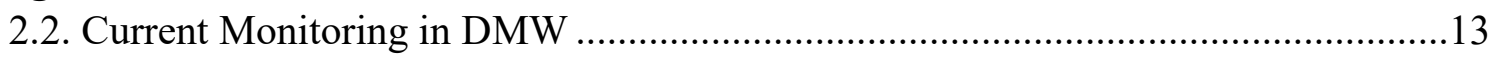

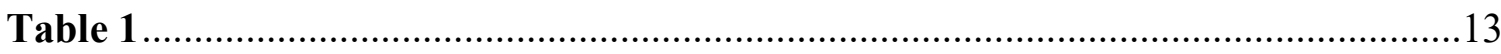

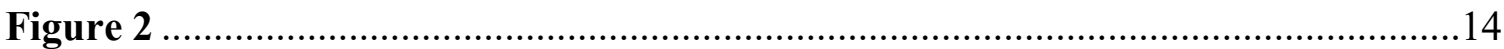

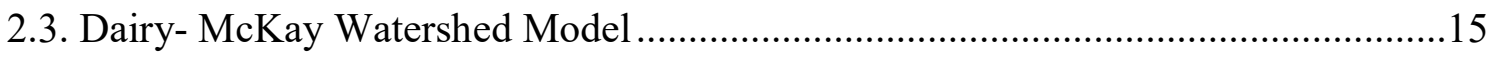

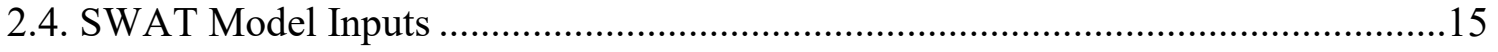

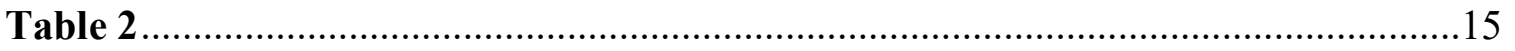

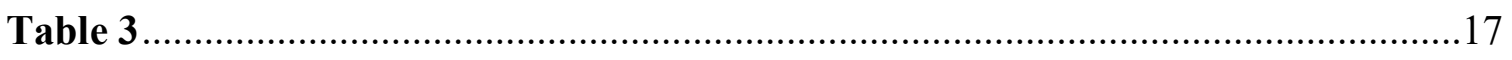

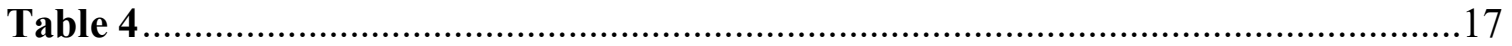

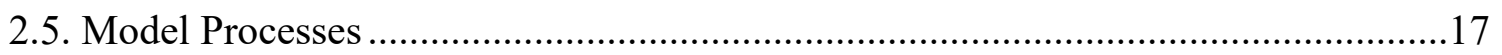

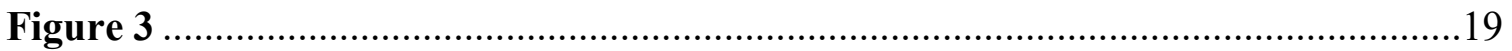

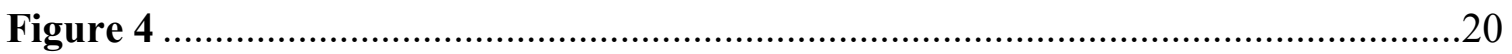

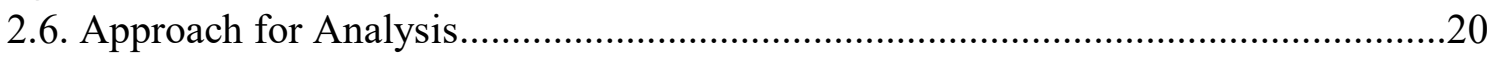

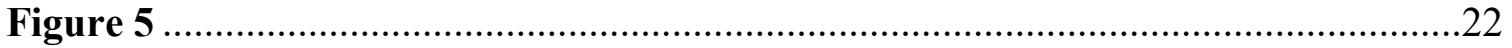

3. Results and Discussion ................................................................................ 23

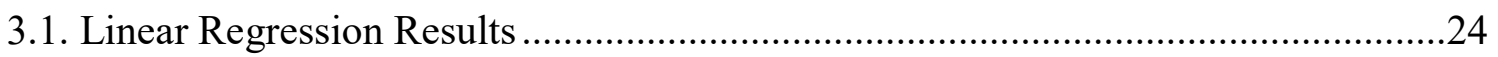

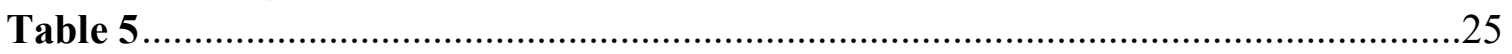

Table 6

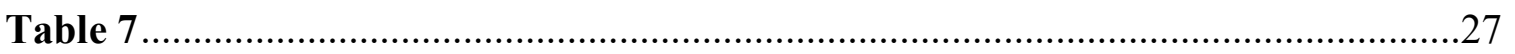

Table 8

Table 9

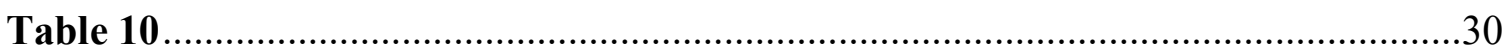

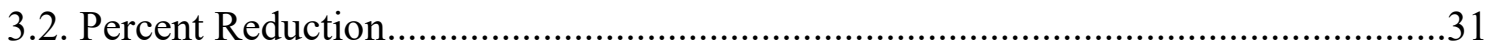

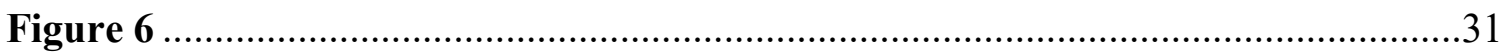

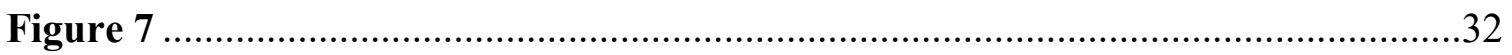

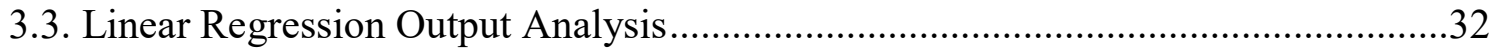

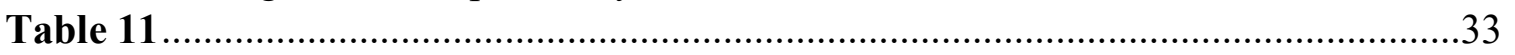

3.4. Proposed Monitoring: Location and Frequency ………….....................................33

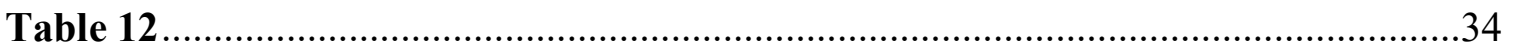

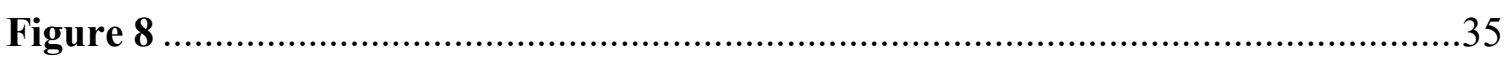

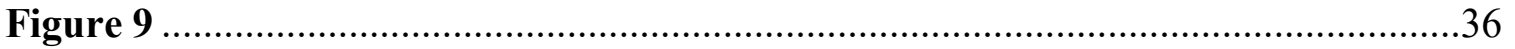




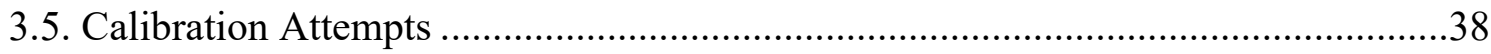

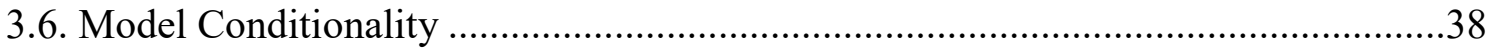

4. Conclusion ..................................................................................................... 41

References ................................................................................................................ 42

Appendices................................................................................. Attached

A. Detailed Landuse Distribution

B. Clean Water Services Flow Restoration, ArcSWAT input

C. Linear Regression Plots 


\begin{abstract}
The project described in this paper specifically looks at the influence of land management practices on water quality, specifically total phosphorus (TP) loads in the Dairy McKay Watershed (DMW). The project is being used to inform a water quality monitoring plan for the Oregon DEQ via outputs from a SWAT model. The DMW is known to have high TP levels that are linked to low dissolved oxygen levels in the Tualatin River. There is a total maximum daily load (TMDL) for the Tualatin River that specifies target TP levels coming out of the DMW, if met these targets are met, the DO levels should remain acceptable for aquatic life in the Tualatin River. As there is little current water quality data within the DMW, it is difficult to identify where the high levels of TP are located and where they can be reduced. The DMW-SWAT model outputs were analyzed, via Linear Regression analysis, to gain a better understanding of which stream segments are most sensitive to TP loading, based on their land use and management. These sensitive stream segments are recommended as future monitoring locations for continuous water quality data in the DMW.
\end{abstract}




\section{Introduction}

\subsection{Point and Nonpoint Source Pollution}

A combination of societal and environmental factors place increasing pressures on local, regional and national water supplies. Adequate water provisions are required for energy and industrial production, agricultural and domestic purposes, as well as protecting ecosystem services (Abbaspour et al., 2015). While quantity of water constitutes one critical aspect of water demands, the quality of water also has an important role. In developed areas, water systems can become contaminated with excessive nutrients, sediments, heat, heavy metals, and other chemical pollutants. Elevated concentrations of any of these contaminants can impair human and/or environmental health. Therefore, it is important for regulatory authorities to improve the understanding of sources and loading rates of pollutants, a critical step in both restoring and managing water quality and quantity in watersheds.

Water supplies can be contaminated via either point or nonpoint sources (NPS). Point sources are identifiable as direct sources of contamination to water sources, such as sewage outfalls or industrial waste outlet (EPA, 2018). In Oregon, the Department of Environmental Quality (DEQ) regulates point source discharge through permits as required by the federal Clean Water Act (CWA), established in 1972. The CWA makes it unlawful to discharge any pollutants from a point source into navigable waters, unless a National Pollution Discharge Elimination System (NPDES) permit is attained (EPA, 2018). This permitting system, controlled at the state level, allows Oregon's DEQ to regulate any industrial, municipal or other facilities that discharge to surface waters. From its formation in 1938 to the development and implementation of NPDES permitting, DEQ's focus was assessing and controlling major point sources of pollution. This consisted of addressing and limiting the sources of pollution, implementing waste water treatment plants, and implementing water quality monitoring networks to document trends in water quality (ODEQ, 2005).

Although point source pollution was the original focus of DEQ efforts, NPS pollution resulting from broad land use practices and urban development have been increasingly recognized as critical for water quality management. Uncovering the associations between land use and water quality is useful for managing land-based pollution (Zhou et al., 2016). Identification and regulation of NPS can be difficult, sourced mainly from land management activities without an immediate known, identifiable source. NPS pollution tends to vary across study areas, particularly among watersheds that have various land uses (Huang et al., 2015). NPS pollution results from contamination during precipitation run-off, atmospheric deposition, leaching, or erosion and is associated with practices in urban, forestry, and agricultural land management (Vymazal and Brezinova, 2015). Agricultural activities, such as fertilizer and pesticide application, are recognized as important factors influencing water quality (Smith et al., 2013). As water moves through landscapes, via runoff or underground flow, it picks up and carries contaminants to finally deposit them in surface or ground waters, making for difficulty in identifying the source of contamination (EPA, 2018). NPS pollution is recognized globally as a 
key factor responsible for waterways degradation (Fraga et al., 2016). The Environmental Protection Agency National Water Quality Inventory indicates that NPS pollution is the major factor preventing the achievement of water quality goals in the United States (Bekele and Nicklow, 2005).

\subsection{Watershed Modeling of NPS}

Water quality monitoring helps assess the impact of point and NPS pollution. Following these assessments, efforts to improve water quality can occur via regulation, NPDES permitting, or through implementation of best management practices (BMP) for NPS. Both water quality monitoring and BMP implementation practices require extensive funding and labor to put in place. Due to their cost, placement of monitoring and BMP is of high importance, NPS models provide a practical alternative to estimate outcomes (Singh et al., 2018). To aid in planning, regulatory and implementation agencies frequently utilize simulation models as a cost-effective tool to identify locations of implementation (Singh et al., 2018).

To gain a better understanding of NPS pollutant loading in Oregon, DEQ utilizes watershed models. These tools can be used to gain a better understanding of how NPS, different management practices, and environmental factors affect water quality. The use of large-scale, high-resolution water resources models enables consistent and comprehensive examination of integrated system behavior through physically-based, data-driven simulation (Abbaspour et al., 2015). A number of watershed models have been developed gain a better understanding of NPS pollution sources, including: Hydrological Simulation Program: FORTRAN (HSPF) (Johanson et al., 2004), Better Assessment Science Integrating Point and Nonpoint Sources (BASINS) (US EPA, 2019), Water Quality Analysis Simulation Program (WASP) (Ambrose et al., 2005), and the Soil and Water Assessment Tool (SWAT) (Winchell et al., 2013). The selection of the model complexity should be driven by the system being studied and the questions being asked (Franks 1995). Of these models, SWAT is frequently used to assess NPS pollution over long timescales and at multiple spatial scales in agricultural watersheds (Ouyang et al., 2016).

\subsection{Phosphorus Loading from NPS}

NPS pollution of phosphorus $(\mathrm{P})$ is a major threat to water quality in many regions, as point source pollution is being controlled effectively ( $\mathrm{Fu}$ et al., 2015). Large amounts of $\mathrm{P}$ in aquatic environments can cause a wide range of problems such as toxic algal blooms, oxygen depletion, and loss of biodiversity, which finally can degrade aquatic ecosystems and the quality of water used for drinking, industry, agriculture, recreation, and other purposes (Sun et al., 2012). Algal growth is commonly limited by the nutrients available to support growth such as P. Excessive growth of algae and other autotrophs, organisms that obtain energy from sunlight and materials from non-living sources, in natural waters can result in significant diel fluctuations in dissolved 
oxygen and $\mathrm{pH}$ which may violate water quality standards put in place to protect aquatic life (Allan and Castillo, 2008). Low DO levels affect all aquatic organisms. Aquatic plants, macroinvertebrates and fish all have acceptable ranges of DO required for their survival. Excessively high or low $\mathrm{pH}$ levels can cause toxic effects ranging from growth and reproduction limitations to death (ODEQ, 2012).

NPS of TP include, but are not limited to: leaky connections between sanitary and storm sewer systems, urban and rural storm runoff, agricultural fertilizers, livestock manure, and erosion of sediment from forestlands and agricultural areas (ODEQ, 2001). Additionally, hobby farms, horse pastures, and small-scale ranches (ranchettes) in rural areas have a higher risk of phosphorus contamination due to little regulation of management techniques (ODEQ, 2001). Failing or overflowing septic systems will contain phosphorus as well as bacteria and other pollutants. These system failure events are common, yet more frequent during the rainy season. Much like these rural "hobby farms", agricultural practices can lead to phosphorus contamination from runoff of fertilizers, animal waste and erosion. It has been widely recognized that intensive agricultural development can increase the watershed load and release more associated pollutants, such as nitrogen, phosphorus and heavy metals (Ouyang, et al., 2016). Forestry contributions to phosphorus levels in are minimal, predominantly associated with roads and culverts (ODEQ, 2001). Finally, instream or near-stream erosion can elevate levels for soils rich in phosphorus.

\subsection{Tualatin River TMDL}

1.4.1. Development and implementation. In Oregon, DEQ regulates water quality in part through total maximum daily loads (TMDLs). Through TMDL development, DEQ determines the amount of a pollutant that a water body can receive without violating the applicable water quality standard, which are designed to protect designated beneficial uses. TMDLs include: conducting intensive watershed assessments, characterizing pollutant sources and loads, developing conceptual and mathematical models, and establishing load and waste-load allocations (ODEQ, 2018). Designated beneficial uses in the Tualatin River include: salmonid spawning and rearing, resident fish and aquatic life, anadromous fish passage, water contact recreation, and aesthetic quality (ODEQ, 2012). The greater Tualatin Watershed is important habitat for steelhead trout, cutthroat trout, and coho salmon. Protecting habitat for native steelhead trout is of importance as they are currently listed as threatened under the Endangered Species Act. Coho salmon were not previously able to access the Tualatin River, although the introduction of fish ladders at Willamette Falls has allowed for access to the Tualatin River. Coho lay eggs and spawn in very shallow, narrow waterways. Tributaries to the Tualatin River, such as Dairy Creek, are suitable spawning grounds, while the Tualatin River provides plentiful habitat for juvenile coho rearing (Gaston, 2010). Like the steelhead trout, several populations of coho salmon are listed as threatened or even endangered under the Endangered Species Act, 
therefore coho are also an important species to protect within the Tualatin River Watershed. Amphibians of concern within the Tualatin River Watershed include the red-legged frog, tailed frog and the Columbia torrent salamander; all listed as sensitive species in Oregon and it is important to maintain water quality standards necessary for these residential aquatic life.

Extensive data collection and modeling for the 1998 Tualatin TMDL demonstrated that TP concentrations had a large influence on algal populations (ODEQ, 2012). Therefore, limiting TP concentrations in water should reduce the incidence and density of algal blooms (ODEQ, 2012). The overall goal of the TMDL was to reduce the chlorophyll a, an indicator of phytoplankton biomass, concentration in the mainstem of the Tualatin River to a three-month average of 0.015 $\mathrm{mg} / \mathrm{L}$ or less. An additional goal of the TMDL was to constrain $\mathrm{pH}$ values between 6.5 and 8.5. To meet the desired chlorophyll a concentration, DEQ determined that TP concentrations needed to be reduced to a monthly median of $0.07 \mathrm{mg} / \mathrm{L}$ or less (ODEQ, 2001). The target concentrations were set for specific locations along the mainstem of the Tualatin and at the mouths of the major tributaries, including the Dairy-McKay, to ensure that water quality in the Tualatin River met standards for aquatic life. Historically, nuisance algal blooms occurred seasonally during June, July and August (ODEQ, 2012) and affected DO and pH levels. The TMDL for TP was intended to meet $\mathrm{pH}$ and $\mathrm{DO}$ criteria.

1.4.2. Progress of the TMDL in Tualatin River Watershed. Based on water quality information, the 1988 TMDL target concentrations were found to be lower than estimates of background phosphorus concentrations in the basin. Thus, the 2001 TMDL revised the TP allocations to commensurate with background phosphorus concentrations. Both TMDLs addressed elevated chlorophyll a concentrations and $\mathrm{pH}$ standard violations. The listed reaches now have an EPA approved TMDL for chlorophyll a, phosphorus and $\mathrm{pH}$. Water quality data from the lower Tualatin River show that TP concentrations now meet the 2001 TMDL allocations and violations of $\mathrm{pH}$ no longer occur in the listed reach (ODEQ, 2012). However, segments of the Tualatin River Watershed still need improvements to water quality, including addressing high TP levels in the Dairy-McKay Watershed. With the Tualatin TMDL implemented and updated, regulators and stakeholders are tasked to identify and mitigate potential sources of contamination.

\subsection{Site Selection}

The Dairy-McKay Watershed (DMW), the northern most portion of the Tualatin River Watershed, was selected for this study due to United States Department of Agriculture (USDA) Natural Resource Conservation Service (NRCS) funding. NRCS awarded the Tualatin Soil and Water Conservation District (TSWCD) a Regional Conservation Partnership Program (RCPP) Grant for restoration efforts to reduce TP within the watershed. The RCPP Grant was awarded to TSWCD for a timeline of 2016 to 2021 , totally $\$ 936,052$. This grant builds on ten years of 
TSWCD work with the NRCS, funded by the Conservation Reserve Enhancement Program (CREP) and the Environmental Quality Incentives Program (EQIP). The funds are intended for water quality enhancement projects within the DMW including: establishing riparian buffers, irrigation efficiency improvements, decrease manure runoff and restoration of wetlands and floodplain sites (TSWCD, 2017).

Due to water quality limitations as well as the RCPP funding, the DMW was chosen as a case study for the Conservation Effectiveness Partnership (CEP). The CEP is an inter-agency initiative among ODEQ, NRCS, Oregon Department of Agriculture (ODA), and the Oregon Watershed Enhancement Board (OWEB). This partnership was established in 2010 to identify watersheds with common natural resource priorities and historical restoration investments. With the DMW case study, the CEP aims to improve understanding of the watershed responses to restoration investments. The first goal of the overarching project is to inform the location of sampling sites for a DEQ water quality monitoring proposal. Ongoing monitoring efforts will be used to fulfill CEP goals of understanding a watershed response to restoration efforts.

\subsection{Study Objectives}

The goal of this study was to assess phosphorus inputs to subwatersheds within the DMW. The specific objectives were to:

- Develop a watershed model to identify appropriate monitoring locations for TP in the DMW and

- Assess the sensitivity of subwatersheds in the DMW to changes in TP loading.

The results from analysis will be used by ODEQ to inform water quality monitoring in the DMW. Ongoing monitoring will help identify sources and loading rates of TP in DMW and allow an assessment of trends in TP concentrations. This study will help to inform future work on the relationship between management practices, NPS pollution, and instream water quality response. 


\section{Methods}

\subsection{Background of Study Area}

The DMW is the most northern watershed of the Tualatin River Basin in Washington County, Oregon (Figure 1). The Tualatin River Basin is a 712 square-mile drainage west of the Portland Metro area converging to the Willamette River south of Lake Oswego. Draining 231 squaremiles, the DMW is the largest watershed contributing to the Tualatin River, making up nearly one third of the flow. The three major tributaries of the DMW are: West Fork Dairy Creek, East Fork Dairy Creek and McKay Creek. West Fork Dairy and East Fork Dairy come together north of the City of Hillsboro to form Dairy Creek. McKay Creek merges with Dairy Creek north of its confluence to the Tualatin River, within the city of Hillsboro (Townsend, 2018).

Figure 1. The Tualatin River Basin. The Dairy-McKay portion is shown highlighted in pink (Tualatin Watershed Council, 2001).

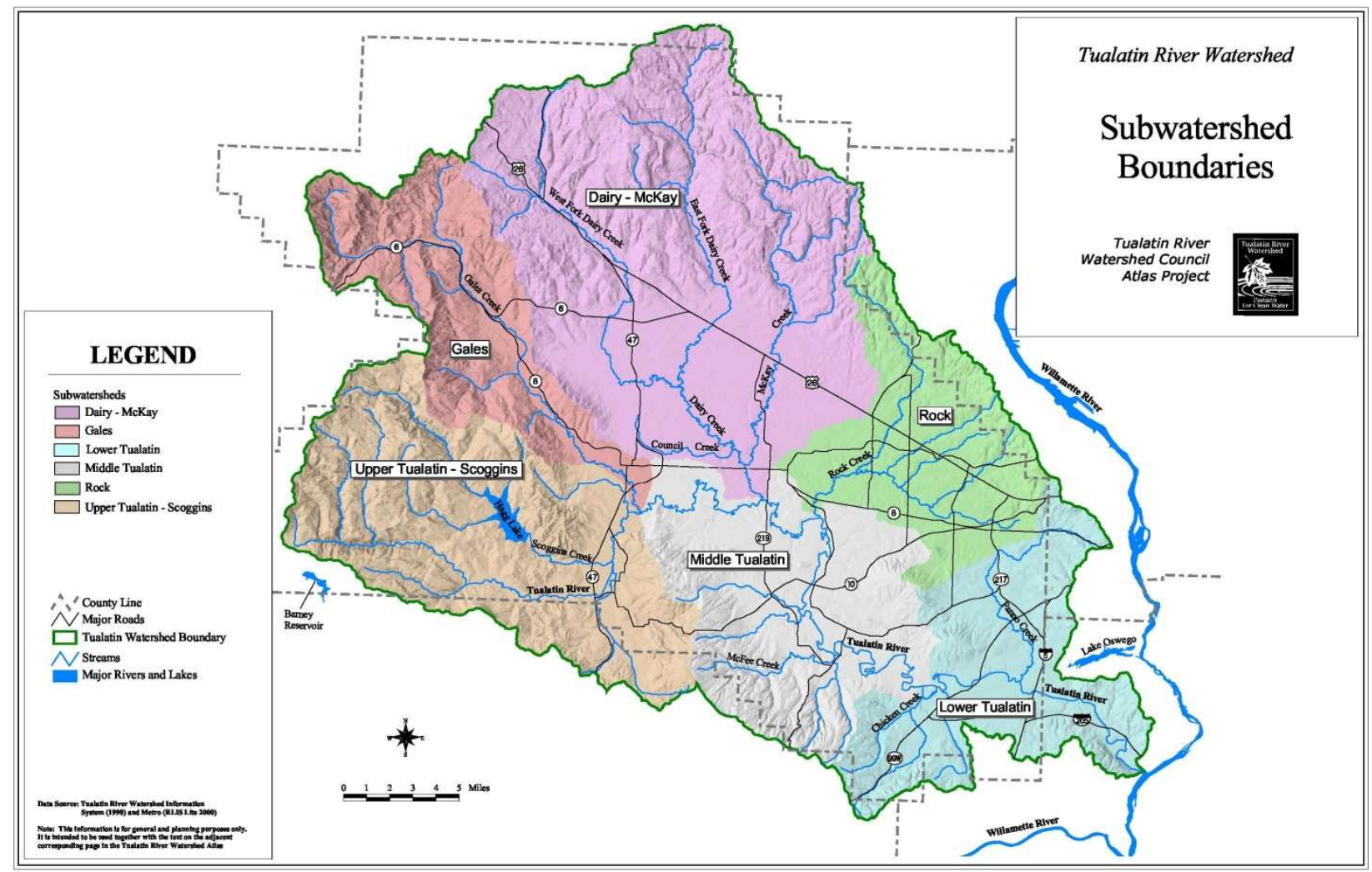

Land use/land cover in the DMW headwaters is dominated by forest, compromising about half of the upper watershed and $24 \%$ of the total watershed. From the headwaters in the Tualatin Mountains, the tributaries to Diary Creek essentially flow in a southerly direction. Agricultural practices account for the second largest use within the watershed, accounting for about $40 \%$ of land use of the entire watershed (Townsend, 2018). The agricultural lands are predominantly 
located within the central areas of the watershed and there is a wide variety in crops produced within the agricultural area. Varietal crops within the DMW include: corn, sweet corn, spring barley, spring/winter wheat, oats, pearl millet, spring canola, flax, alfalfa, hay, durum wheat, sugar-beet, pinto beans, potato, tomato, onion, cucumber, lentils, peas, strawberry, red clover, slender wheatgrass, apple, vineyard, almond, orchard, broccoli, peppers, spinach, watermelon, cabbage, cauliflower and carrot (a detailed description of DMW land use distribution can be found in Appendix A). Urban lands make up the most southern portion of the watershed, with $5 \%$ of the watershed located within the Urban Growth Boundaries of North Plains and Hillsboro. Before these towns were established, this land was comprised of prairie lands interspersed with forested areas of the watershed (Townsend, 2018). Dairy Creek enters the Tualatin River at River Mile 45, near the City of Hillsboro (BLM, 1999).

The Tualatin Mountains, at the headwaters of the DMW, are consistently above 1,500 feet in elevation. The highest elevation in the watershed is found within the headwaters of East Fork Dairy Creek at Long Peak, 2,265 feet in elevation. In the mountains, the gradient of the creek ranges between three and ten percent. Moving southerly within the watershed, the Tualatin Mountains gradually descends into the Tualatin Plain, making up the lower third of the watershed. The Tualatin Plain mainly lies below 200 feet in elevation with a slight gradient, generally less than one percent. Dairy Creek flows into the Tualatin at about 115 feet of elevation with a gradient of 0.06 percent. (BLM, 1999)

The lithology and soils of the watershed are variable to location and elevation. The headwaters are primarily composed of Tertiary Marine sedimentary formations and Columbia River basalt. The valley below the mountains was deposited during the Pleistocene flooding, also known as the Missoula floods. These floods were the result of massive glacial lake outbursts, depositing layers of gravel, sand, silt and clay in the Tualatin Valley, bringing the valley's elevation to about 250 feet. Due to the lacustrine silt and clay deposits, the Tualatin Valley Basin has many soils with low permeability, resulting in poor drainage conditions (Orr et al., 1992). The soils in the Tualatin Mountains are typically Alfisols and Inceptisols, generally fine grained with a large silt component. The Columbia River basalt produces Adisols and Utisols, which are unstable and prone to erosion, particularly common in the McKay Creek drainage (Orr et al., 1992). Soils in the headwaters hold moderate to deep loams, providing high-nutrient soils to the Tualatin Valley. Groundwater phosphorus levels in the Tualatin Valley are naturally high, potentially resulting in the high soil phosphorus levels (TAC, 1997). Similarly, the soil phosphorus levels in the forested sections of the watershed, specifically those developed from sedimentary lithology, reflect naturally high phosphorus levels seen in the groundwater (Wolf, 1992).

The Dairy McKay Watershed has a moderate climate with seasonal flow fluctuations. The summers are characterized by warm and generally dry weather, while the winters are cool and wet. The majority of precipitation events occur between October to March (BLM, 1999). The amount of precipitation varies within the watershed, decreasing in frequency in correspondence with elevation. The Tualatin Mountains historically receive approximately 67 inches of precipitation each year, while the Tualatin Plains, near Hillsboro, receive roughly 38 inches (BLM, 1999). Flows in the DMW peak in the winter with very low flows in the summer, 
spurring the seasonal flow augmentation discussed later. Due to the lacustrine silt and clay deposits in the lower portion of the watershed, flooding frequently occurs during rainfall events. Poor infiltration and low gradient in this alluvial plain provided substantial area for historical wetlands, before settlement and land-conversion for agriculture in the valley.

\subsection{Current Monitoring in DMW}

Current water quality monitoring locations within the DMW (Table 1) occur at ORDEQ stations 22457 located on East Fork Dairy, 11497 located on Dairy Creek before confluence with McKay, 22438 on McKay Creek, and 10491 at the Dairy-McKay confluence to the Tualatin River (Figure 2). Monitoring at ORDEQ-22457 is for continuous flow, recorded daily, with sporadic grab-samples of water quality parameters since 2001. ORDEQ-11497 has been reporting weekly water quality parameter samples since 2006. ORDEQ-22438 also reports weekly water quality parameters, but has only been active since 2008. Finally, ORDEQ-10491 has the most long-term data collection. At this station, water quality parameter sampling has been collected since 1991 multiple times a month, with some inconsistency and data gaps.

Table 1. DMW current monitoring stations, sampling dates, frequency and parameters.

\begin{tabular}{|l|l|l|l|}
\hline \multicolumn{1}{|c|}{ Station ID } & \multicolumn{1}{|c|}{$\begin{array}{c}\text { Dates } \\
\text { Sampled }\end{array}$} & Frequency & \multicolumn{1}{c|}{ Parameters Sampled } \\
\hline $\begin{array}{l}\text { ORDEQ- } \\
\text { 22457 }\end{array}$ & $\begin{array}{l}12 / 6 / 2001- \\
9 / 14 / 17\end{array}$ & $\begin{array}{l}\sim \text { or } 2 \text { per } \\
\text { year }\end{array}$ & $\begin{array}{l}\text { flow, temperature, WQ } \\
\text { parameters }\end{array}$ \\
\hline $\begin{array}{l}\text { ORDEQ- } \\
\text { 22438 }\end{array}$ & $\begin{array}{l}5 / 6 / 2008- \\
11 / 17 / 2016\end{array}$ & $\begin{array}{l}\text { summer, } \\
\text { weekly }\end{array}$ & temperature, WQ parameters \\
$\begin{array}{l}\text { ORDEQ- } \\
\text { 10491 }\end{array}$ & $1 / 7 / 1991-$ & $\begin{array}{l}\text { weekly in } \\
\text { more recent } \\
\text { years }\end{array}$ & temperature, WQ parameters \\
\hline $\begin{array}{l}\text { ORDEQ- } \\
\text { 11497 }\end{array}$ & $\begin{array}{l}8 / 1 / 17 / 2016 \\
11 / 17 / 2016\end{array}$ & weekly & temperature, WQ parameters \\
\hline
\end{tabular}


Figure 2. Map of current monitoring within the Dairy McKay Watershed.

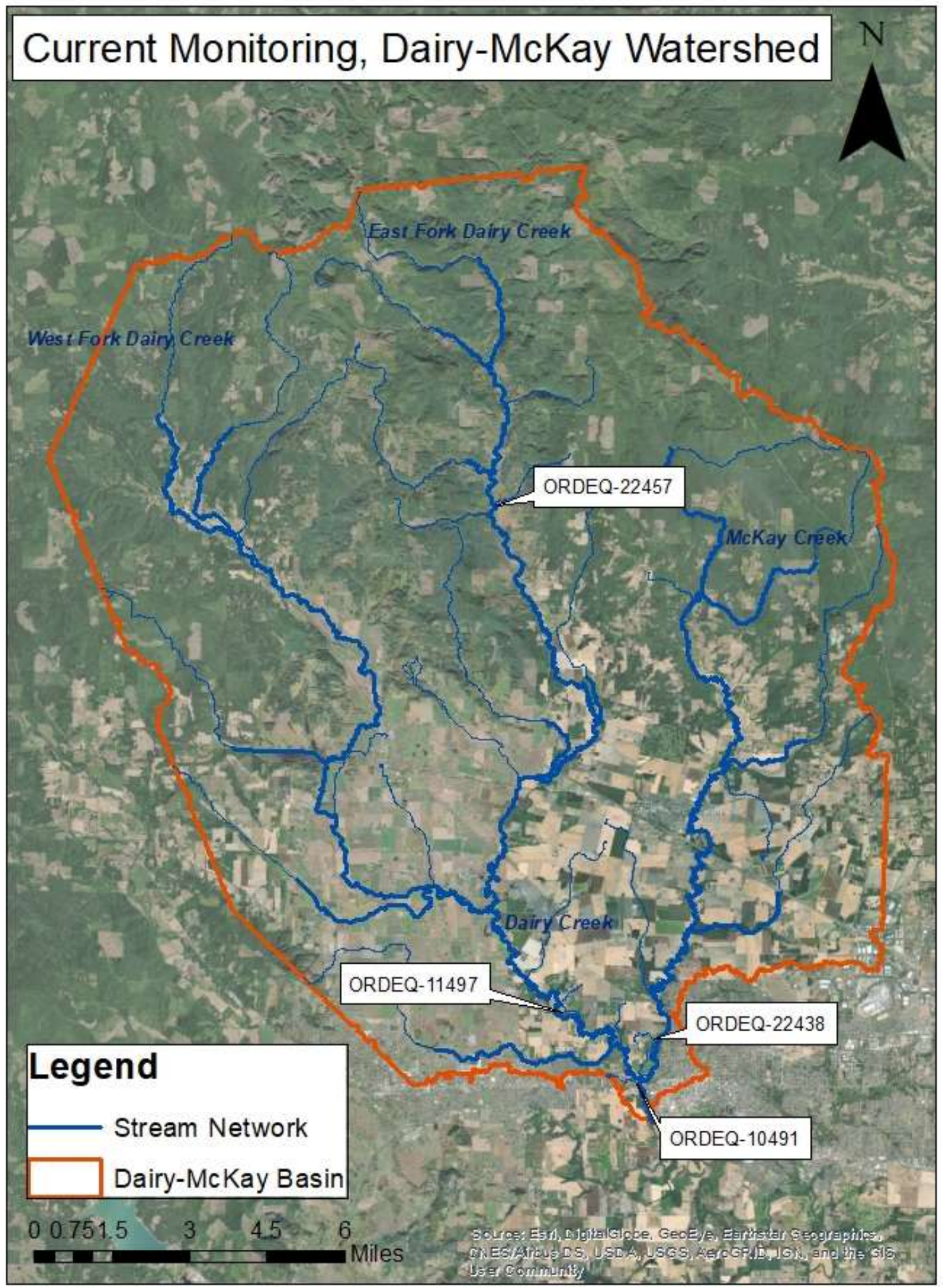




\subsection{Dairy-McKay Watershed Model}

The model chosen to simulate TP export from the DMW was the Soil and Water Assessment Tool (SWAT) (Winchell et al., 2013). SWAT was chosen for this study for its capacity to simulate the effect of land management processes on water quality at the watershed, subwatershed and land use/land cover. SWAT is a physically based model, using detailed information of weather data, point source information, soil parameters, topography, vegetation and land management practices. Physical processes of water and sediment movement, crop growth and nutrient cycling are modeled from this data (Neitsch et al., 2000). SWAT evaluates the influence of different land management scenarios on water quality and quantity in river basins, particularly non-point source pollution coming from specified management activities. SWAT performs this evaluation as a continuous-time, semi-distributed, process-based river basin model (Arnold et al., 1998).

\subsection{SWAT Model Inputs}

SWAT data inputs are summarized in Table 2. The DMW SWAT Model was developed with ArcSWAT 2012.10, compatible with ArcGIS 10.4 version. Most of the data were available from USDA's NRCS Geospatial Data Gateway (downloaded April 23, 2018). The remaining data were derived within SWAT software, via conversations with relevant agencies or via download from other sources. All necessary data was set spatially to NAD_1983_2011_StatePlane_Oregon_North_FIPS_3601.

Table 2. Model inputs for the Dairy-McKay Watershed. Data was collected from datagateway.nrcs.usda.gov unless noted otherwise.

\begin{tabular}{|c|l|}
\hline Input Data & \multicolumn{1}{|c|}{ Description } \\
\hline Elevation & National Elevation Dataset, 10-m resolution \\
\hline Slope & 3 Classes: 0-15\%, 15-40\% and $>40 \%$ \\
\hline Stream Network & DEM-derived within ArcSWAT \\
\hline Land Use & USDA-NASS Cropland Data Layer, 30-m resolution \\
\hline Soil & SSURGO 2.2, 1:12,000 scale \\
\hline Meteorological & Forest Grove, Oregon AgriMet Weather Station (FOGO) \\
\hline Agricultural Management & EPA- Willamette crop management standards \\
\hline Point Source & CWS Flow Restoration Reports, Springhill Pump records (USGS) \\
\hline Best Management Practices & USDA NRCS- Practice Points data layer 2018 \\
\hline
\end{tabular}

The elevation datum is a compilation from 17 digital elevations models (DEMs) from the National Elevation Dataset of the DMW. The 17 DEMs were compiled to one DEM covering the entire watershed and input to SWAT. The combined DEM holds a ten meter resolution. The 
land use/land cover datum consists of information collected by the United States Department of Agriculture (USDA), National Agricultural Statistics Service (NASS) to create the Cropland Data Layer (CDL). The 30-meter resolution USDA-NASS CDL is an annual raster, georeferenced, crop-specific land cover data derived from satellite imagery. The 2017 Oregon CDL was chosen for this project to depict the most current agricultural practices within the watershed and to model the effects of current land use on TP loading and transport throughout the DMW. The USDA-NRCS Soil Survey Spatial and Tabular Data (SSURGO) was also used. The SSURGO database contains information about soils collected by the National Cooperative Soil Survey over the course of a century. Examples of information available from the database include available water capacity, soil reaction, electrical conductivity, and frequency of flooding; yields for cropland, woodland, rangeland, and pastureland; and limitations affecting recreational development, building site development, and other engineering uses. SSURGO data are compiled at scales ranging from 1:12,000 to 1:63,000 and is intended for use in natural resource planning.

Meteorological data were downloaded from the Forest Grove, Oregon AgriMet Weather Station. Daily averages for solar radiation, maximum and minimum temperature, precipitation, relative humidity, and wind speed were available for the simulation period, January 2008 to December 2017. Agricultural management standards for the Willamette Valley were provided by the U.S. Environmental Protection Agency (EPA) (Jiajia Lin, US EPA, personal communication), noted in Table 3. Best Management Practices (BMPs) funded within the DMW were compiled by NRCS and shared for project inputs. 187 ArcSWAT-compatible, historical BMP practices within the DMW were entered into the model and can be found in the Table 4. The final model input was from Clean Water Services (CWS) Flow Restoration Reports (CWS, 2017). These seasonal flow restoration projects are implemented during seasonal low flows to control water temperature and dilute potential nutrient contamination. The flow restoration occurs from midJuly to mid-October at three locations within the watershed: McKay Creek (river mile 7.0), East Fork Dairy Creek (river mile 4.9) and West Fork Dairy Creek (river mile 5.2). The flow quantity, in cubic feet per second (cfs), was extracted from CWS reports and quality of flow was retrieved from USGS records (USGS, 2016). These data can be found in the Appendix B. 
Table 3. Contains crop standards for the Willamette Valley. These standards were compiled by Jiajia Lin from the US EPA and intended for ArcSWAT input, her source is noted as the data source. For fertilizer rates with a range, the median value was used for model input.

\begin{tabular}{|c|c|c|c|}
\hline Crop & Fertilizer (lb. N/ha/yr.) & Crop Harvest & Data Source \\
\hline Perennial ryegrass & 150 to 200 & Early July & Hart et al., 2005a \\
\hline Orchardgrass & 110 to 140 & August/September & Doerge et al., 2000 \\
\hline Pasture & 100 to 120 & Spring/Summer/Fall & Pirelli et al., 2004 \\
\hline Clover & 0 & May & Gardner et al., 2000 \\
\hline Hay & 40 to 90 & $1 / 2$ Spring, $1 / 2$ Summer & Personal communication \\
\hline Wheat & 100 to 230 & August & Hart et al., 2009a \\
\hline Bentgrass & 100 to 130 & August & Gardner et al., 1999 \\
\hline Caneberry & 50 to 70 & Spring & Hart et al., 2006a \\
\hline Corn & 40 to 215 & September & Hart et al., 2009c \\
\hline Orchard crops & 15 to 50 & August & Righetti et al., 1998 \\
\hline Vineyard & 0 to 6 & Summer & Personal communication \\
\hline Strawberries & 25 to 50 & Spring/Summer & Hart et al., 2000 \\
\hline
\end{tabular}

Table 4. Number of best management practices in the Dairy-McKay Watershed that were modeled in ArcSWAT.

\begin{tabular}{|c|c|}
\hline NRCS Practice & Number Modeled \\
\hline Waste Storage & 2 \\
\hline No Till & 137 \\
\hline Cattle Fence & 5 \\
\hline Riparian Buffer & 43 \\
\hline
\end{tabular}

\subsection{Model Processes}

The SWAT model delineates a watershed by dividing a watershed into subwatersheds. Based on the DMW stream network, SWAT delineated 31 subwatersheds Figure 3. Furthermore, these subwatersheds are refined by hydrological response units (HRUs), which are areas lumped together based on similar land use/land cover, soil type and slope. HRUs are physically homogeneous non-contiguous areas assumed to respond similarly to inputs (Li et al., 1977). Land management activities are modeled at the HRU level, allowing for analysis of changes in water quality parameters due to management scenarios. The user sets a specified threshold percentage for land use, soil and slope; the smaller the threshold, the more detail is provided in the HRU distributions. Thresholds from 5 to $15 \%$ are commonly used; however, model applications have been run with lower or no thresholds when it is important to preserve each unique landscape feature in the model representation (Chiang et al., 2010). Since crops grown in the DMW are of high variety and this study is focused on identifying NPS of phosphorus, a 
threshold of $2 \%$ was chosen for land use. The threshold for soil and slope were both set to $10 \%$ as commonly-used thresholds range from 5 to $15 \%$ (Singh et al., 2018). These thresholds led to a delineation of 1,264 HRUs within the DMW-SWAT model (Figure 4). For example, subwatershed number one has four land uses that are over two percent threshold as well as four soil types and three slope categories that cover over ten percent of the area of this specified subwatershed. These land uses, soils and slopes combine to make 37 HRUs for subwatershed one, each of which can be modified for management and BMP's as necessary. 
Figure 3. Displays a map of 31 ArcSWAT delineated subwatersheds for the Dairy-McKay Watershed.

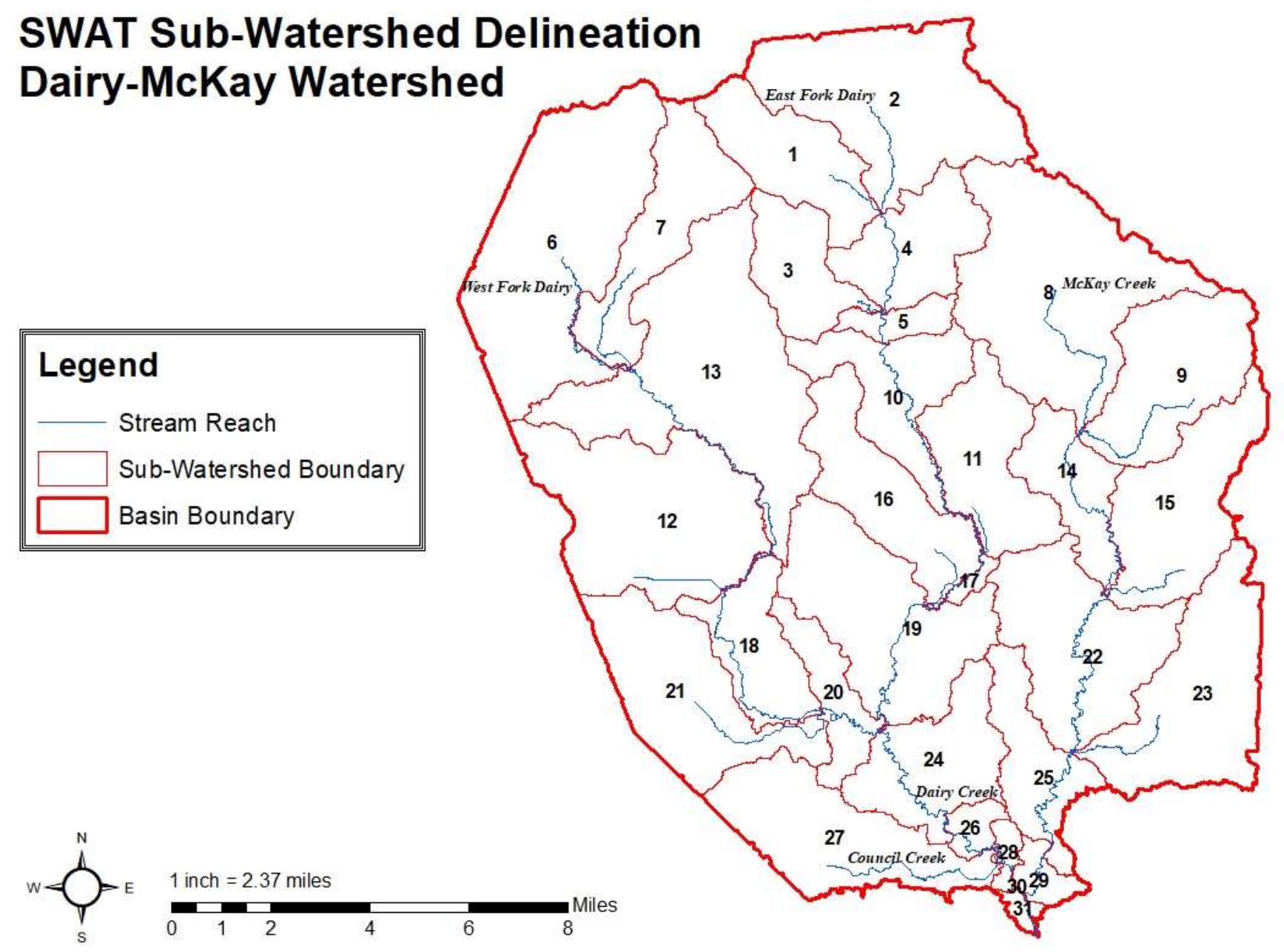


Figure 4. Delineation of DMW-SWAT HRU.

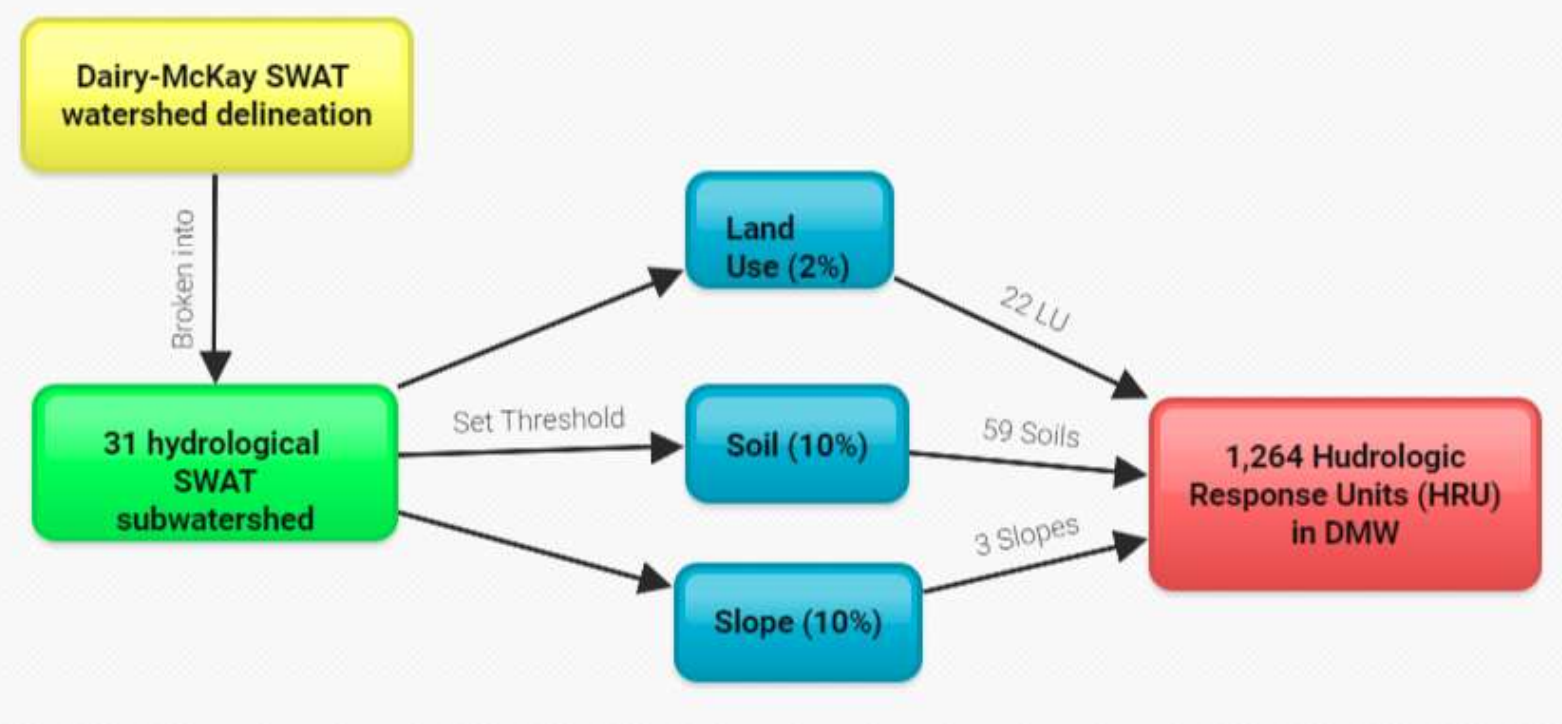

Following the HRU delineation, the user is able to adjust model inputs. Willamette Valley crop agricultural standards were adjusted at the basin-wide scale and BMPs were input at the HRU scale. The input files are then rewritten to include the adjusted parameters and the model is then ready for simulation. For this study, SWAT was run for a period of ten years, 2008 to 2017, with a three-year warm-up period. A warm-up period is necessary to stabilize the modeled movement of water within the system, as the model begins with no water in streams or reservoirs, it is suggested that one or more years of warm-up period be used. Outputs were reported at the daily time-step, meaning that modeled flow and water parameter values were retrieved as daily averages for the seven-year simulation period.

\subsection{Approach for Analysis}

Abbaspour et al. (2015) identified four parameters that affect TP loading and movement through SWAT models: PSP.bsn, ERORGP.hru, BC4.swq and RS5.swq. Of those parameters, ERORGP was selected as the parameter of interest for this study. ERORGP represents the phosphorus enrichment ratio with sediment loading, defined as the ration of concentration of phosphorus transported with the sediment to the concentration of phosphorus in the soil surface layer (Neitsch et al., 2000). ERORGP is modeled at the HRU level, allowing manipulation of phosphorus enrichment from specified land uses. The parameter range for ERORGP is from the default of 0 to a maximum of 5 and if left at 0 , SWAT will calculate the enrichment ratio.

To perform the sensitivity analysis of ERORGP, the value was changed from 0 to 1 at the watershed level and ran to account for the "Base Model". To perform analysis of TP loading at the subwatershed level, each of the 31 subwatersheds were individually manipulated. Each subwatershed's ERORGP was raised from 1 to 2.5, while the remaining 30 subwatershed's 
ERORGP was left at 1. Manipulating the ERORGP parameter values identifies reaches of the watershed that are most sensitive to phosphorus loading at the land management level. All other model parameters were kept the same and each subwatershed was simulated with equivalent time period as the "Base Model". The result of the comparison is a linear function that, as accurately as possible, predicts the dependent variable values as a function of the independent variables (Schlegel, 2018).

The subwatersheds were then compared at the DMW outlet to the Tualatin River, subwatershed 31 outlet, as well as at the individual subwatershed level. The relationship of the manipulation to "Base Model" was analyzed by performing a linear regression analysis for load, concentration and yield. Linear regression was used to better understand the relationship between the base model outputs, plotted on the $y$-axis, to the manipulated model outputs, $x$-axis. Performing the linear regression analysis this way will show a reduction in TP when comparing the datasets. The linear regression was forced through 0 to show the percent change between the two datasets according to the slope of the linear regression. Figure 5 provides a summary flow of the analytical process for this projects' model, DMW-SWAT, outputs.

To test the sensitivity of stream segments to phosphorus loading at the land management level, I created linear regression models. These linear models compare the 31 individual model runs of elevated phosphorus enrichment, based off ArcSWAT delineated subwatersheds, to the data from the base model run that holds a uniform phosphorus enrichment ratio for all subwatersheds. The slope from these linear models reflect the percent reduction in TP at the subwatershed level.

The slope, $a$, of the linear regression analysis displays the linear relationship between the base model outputs (all SW EROGP=1), $y$, to manipulated model outputs, $x$, via the equation $y=a x$. By forcing the linear regression through 0 , the slope displays a linear relationship from manipulated to base model runs as a reduction in TP load, concentration and yield. Therefore smaller values for slope provide analytical support that the manipulated data will show more variation from the original model outputs. The subwatershed with the largest variation, displayed as the smallest slope when comparing subwatershed's, denotes the largest reduction in TP from a uniform reduction in TP enrichment. The data was looked at in terms of load, concentration and yield to eliminate the variability in subwatershed flow and area. To get the percent reduction, $R$, of TP load, concentration and yield, we use the slope of the linear regression, $a$, in the following equation $R=(1-a) * 100$. This allows for better visual representation of the TP reactions to hypothetical BMP implementations at the subwatershed level. The scenarios ran by the model display a uniform reduction in Phosphorus enrichment from land management actions at the subwatershed level. By analyzing the percent reduction in TP load, concentration and yield at both the watershed and subwatershed scale, we are able to see which subwatersheds land management has the most influence on Phosphorus levels in the DMW. This information can then be used to recommend that future monitoring occur at the locations with highest variability to get a ground-truth representation of Phosphorus cycling in the watershed. 
Figure 5. Flow chart summarizing the linear regression analysis of outputs for DMW-SWAT model.

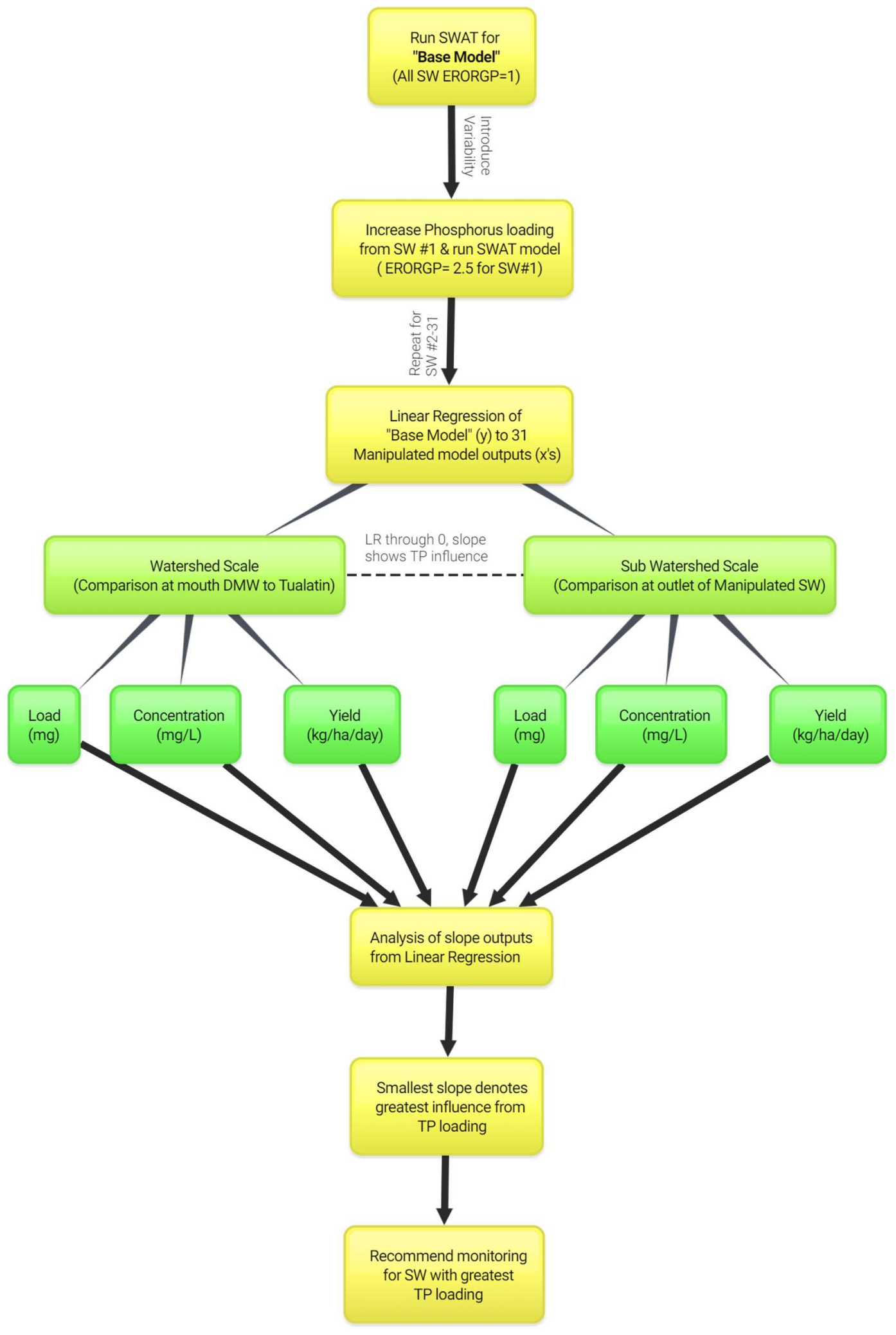




\section{Results and Discussion}

Attempts to calibrate the DMW-SWAT model proved unsuccessful. Repetitive errors received in DMW-SWAT calibration attempts indicated insufficient data. My conjecture as to why this error surfaced during calibration attempts was due to the location of available continuous flow data within the watershed. For calibration, flow records must match DMW-SWAT outputs with continuous daily records from 2008 to 2017 . The only continuous flow data that matches this time-period are located on East Fork Dairy Creek, ORDEQ-22457. This station drains only 33.8 of the watershed's 231 square miles, meaning data from this station does not represent total flow within the DMW and resulting in insufficient data errors when attempting to calibrate flow outputs. Due to the location of the gage station, there is no reference of flows for West Fork Dairy Creek, McKay Creek or upon their confluence with East Fork Dairy Creek to form DairyMcKay Creek. Flow data from a point in the watershed following the confluence, close to the mouth of DMW to the Tualatin River, would be ideal for future calibration attempts. Multiple gauges of continuous flow data will give a more accurate depiction of watershed flows.

Though calibration proved unsuccessful with current flow data, data from ORDEQ-22457 may still be appropriate for future calibration efforts, though not explored in this study. Available data could be employed to interpolate flow near the mouth of the watershed, utilizing the historical flow and weather data records. Due to time constraints with the project, this method was not explored but could be useful for the future DMW-SWAT model calibration attempts, without additional continuous flow data.

Another aspect of SWAT-CUP, consistent in application for manual calibration, is user error. The experience of modelers can make a substantial difference in model calibration. The DMWSWAT model preparation and calibration was performed with novice watershed modeling understanding, with myself as the modeler. I was aware of ecosystem models and their application before starting the process, but I had no prior experience in the modeling or calibration process. This is important to note, yet the application of SWAT-CUP is intended to decrease modeler uncertainty by removing probable sources of modeling and calibration errors (Abbaspour, 2015). To decrease user error, I also received help with calibration errors from the SWAT-CUP Google group, including direct assistance from Karim C. Abbaspour, a SWATCUP developer. Even so, calibration attempts proved ineffective.

Though modeling can be an employable tool for resource management and restoration, it is important to acknowledge the limitations. Uncertainty characterizes both the technical and philosophical aspects of the ecological modeling endeavor (Arhonditsis and Brett, 2004). Much of this discrepancy is due to uncertainties in the conceptual framework of modeling programs and the irregularity of ecological processes. For example, within SWAT there is an assumption that the universal soil loss equation is applicable to all estimates of sediment loss during erosion processes. This can be scrutinized similarly for each process inlayed within hydrologic modeling, as there can be exceptions for each "universal" processing equation. Also, large impact, short duration natural processes can occur within a watershed that have an effect on water quality yet are not within the model concept framework, such as dust storm or a landslide. 
Because the DMW-SWAT model was not calibrated, the outputs were not assessed for their ability to obtain a fit to observed water quality data. Since the model will be used to inform a future monitoring plan, the outputs are being used to identify potential sources of Phosphorus. The DMW-SWAT model takes into account current soil properties and land uses of the DMW, standard management of the specified land uses for the Willamette River Basin as well as recorded applications of conservation actions (BMP) within the watershed. When looking at the DMW as a whole, these factors give an accurate depiction of locations where increased phosphorus enrichment occurs within the watershed. By strategically placing water quality monitoring stations that are based on the analysis of DMW-SWAT outputs, the ODEQ will be able to utilize incoming water quality data to improve the focus of future practices aimed to enhance water quality in the basin. Though the DMW-SWAT model outputs adequately informs monitoring locations, it is important to identify limitations, challenges and uncertainties of the DMW-SWAT modeling process for more informed future studies.

\subsection{Linear Regression Results}

All manipulated subwatersheds linear relationships to the load, concentration, and yield of the base model outputs are shown in Tables 5-10 at both the watershed and subwatershed scale. The linear regression plots used to compile these tables can be found in Appendix C. 
Table 5. Watershed scale values from the linear regression analysis of TP Load.

\begin{tabular}{|c|c|c|c|}
\hline SW ID & Slope & Std. Error & $\mathbf{R}^{\mathbf{2}}$ \\
\hline $\mathbf{1}$ & 0.984 & $2.23 \mathrm{E}-04$ & 0.9999 \\
\hline $\mathbf{2}$ & 0.979 & $2.64 \mathrm{E}-04$ & 0.9998 \\
\hline $\mathbf{3}$ & 0.989 & $1.51 \mathrm{E}-04$ & 0.9999 \\
\hline $\mathbf{4}$ & 0.986 & $1.78 \mathrm{E}-04$ & 0.9999 \\
\hline $\mathbf{5}$ & 0.998 & $2.87 \mathrm{E}-05$ & $>0.999$ \\
\hline $\mathbf{6}$ & 0.988 & $1.66 \mathrm{E}-04$ & 0.9999 \\
\hline $\mathbf{7}$ & 0.972 & $3.21 \mathrm{E}-04$ & 0.9997 \\
\hline $\mathbf{8}$ & 0.982 & $2.15 \mathrm{E}-04$ & 0.9999 \\
\hline $\mathbf{9}$ & 0.988 & $1.44 \mathrm{E}-04$ & 0.9999 \\
\hline $\mathbf{1 0}$ & 0.990 & $1.36 \mathrm{E}-04$ & $>0.999$ \\
\hline $\mathbf{1 1}$ & 0.966 & $2.20 \mathrm{E}-04$ & 0.9999 \\
\hline $\mathbf{1 2}$ & 0.942 & $2.94 \mathrm{E}-04$ & 0.9998 \\
\hline $\mathbf{1 3}$ & 0.972 & $1.07 \mathrm{E}-04$ & $>0.999$ \\
\hline $\mathbf{1 4}$ & 0.989 & $1.10 \mathrm{E}-04$ & $>0.999$ \\
\hline $\mathbf{1 5}$ & 0.980 & $1.53 \mathrm{E}-04$ & 0.9999 \\
\hline $\mathbf{1 6}$ & 0.987 & $1.44 \mathrm{E}-04$ & 0.9999 \\
\hline $\mathbf{1 7}$ & 0.999 & $7.14 \mathrm{E}-06$ & $>0.999$ \\
\hline $\mathbf{1 8}$ & 0.976 & $2.00 \mathrm{E}-04$ & 0.9999 \\
\hline $\mathbf{1 9}$ & 0.973 & $2.17 \mathrm{E}-04$ & 0.9999 \\
\hline $\mathbf{2 0}$ & 0.992 & $7.02 \mathrm{E}-05$ & $>0.999$ \\
\hline $\mathbf{2 1}$ & 0.962 & $2.24 \mathrm{E}-04$ & 0.9999 \\
\hline $\mathbf{2 2}$ & 0.974 & $3.07 \mathrm{E}-04$ & 0.9997 \\
\hline $\mathbf{2 3}$ & 0.957 & $2.37 \mathrm{E}-04$ & 0.9998 \\
\hline $\mathbf{2 4}$ & 0.987 & $2.49 \mathrm{E}-04$ & 0.9998 \\
\hline $\mathbf{2 5}$ & 0.979 & $1.50 \mathrm{E}-04$ & 0.9999 \\
\hline $\mathbf{2 6}$ & 0.994 & $2.70 \mathrm{E}-05$ & $>0.999$ \\
\hline $\mathbf{2 7}$ & 0.970 & $2.43 \mathrm{E}-04$ & 0.9998 \\
\hline $\mathbf{2 8}$ & 0.998 & $1.74 \mathrm{E}-05$ & $>0.999$ \\
\hline $\mathbf{2 9}$ & 0.997 & $3.83 \mathrm{E}-05$ & $>0.999$ \\
\hline $\mathbf{3 0}$ & 1 & $1.28 \mathrm{E}-07$ & $>0.999$ \\
\hline $\mathbf{3 1}$ & 0.998 & $1.65 \mathrm{E}-05$ & $>0.999$ \\
\hline & & & \\
\hline
\end{tabular}


Table 6. Watershed scale values from the linear regression analysis of TP Concentration.

\begin{tabular}{|c|c|c|c|}
\hline SW ID & Slope & Std. Error & $\mathbf{R}^{\mathbf{2}}$ \\
\hline $\mathbf{1}$ & 0.989 & $1.87 \mathrm{E}-04$ & 0.9999 \\
\hline $\mathbf{2}$ & 0.982 & $2.29 \mathrm{E}-04$ & 0.9999 \\
\hline $\mathbf{3}$ & 0.993 & $1.26 \mathrm{E}-04$ & $>0.999$ \\
\hline $\mathbf{4}$ & 0.989 & $1.47 \mathrm{E}-04$ & 0.9999 \\
\hline $\mathbf{5}$ & 0.999 & $2.35 \mathrm{E}-05$ & $>0.999$ \\
\hline $\mathbf{6}$ & 0.986 & $1.84 \mathrm{E}-04$ & 0.9999 \\
\hline $\mathbf{7}$ & 0.984 & $2.51 \mathrm{E}-04$ & 0.9998 \\
\hline $\mathbf{8}$ & 0.985 & $1.78 \mathrm{E}-04$ & 0.9999 \\
\hline $\mathbf{9}$ & 0.987 & $1.25 \mathrm{E}-04$ & $>0.999$ \\
\hline $\mathbf{1 0}$ & 0.992 & $1.17 \mathrm{E}-04$ & $>0.999$ \\
\hline $\mathbf{1 1}$ & 0.965 & $2.58 \mathrm{E}-04$ & 0.9998 \\
\hline $\mathbf{1 2}$ & 0.943 & $3.27 \mathrm{E}-04$ & 0.9997 \\
\hline $\mathbf{1 3}$ & 0.975 & $1.46 \mathrm{E}-04$ & 0.9999 \\
\hline $\mathbf{1 4}$ & 0.987 & $1.09 \mathrm{E}-04$ & $>0.999$ \\
\hline $\mathbf{1 5}$ & 0.980 & $2.01 \mathrm{E}-04$ & 0.9999 \\
\hline $\mathbf{1 6}$ & 0.990 & $1.25 \mathrm{E}-04$ & $>0.999$ \\
\hline $\mathbf{1 7}$ & 0.999 & $8.72 \mathrm{E}-06$ & $>0.999$ \\
\hline $\mathbf{1 8}$ & 0.974 & $2.70 \mathrm{E}-04$ & 0.9998 \\
\hline $\mathbf{1 9}$ & 0.967 & $2.51 \mathrm{E}-04$ & 0.9998 \\
\hline $\mathbf{2 0}$ & 0.992 & $9.02 \mathrm{E}-05$ & $>0.999$ \\
\hline $\mathbf{2 1}$ & 0.963 & $3.08 \mathrm{E}-04$ & 0.9997 \\
\hline $\mathbf{2 2}$ & 0.967 & $3.09 \mathrm{E}-04$ & 0.9997 \\
\hline $\mathbf{2 3}$ & 0.952 & $2.72 \mathrm{E}-04$ & 0.9998 \\
\hline $\mathbf{2 4}$ & 0.987 & $3.01 \mathrm{E}-04$ & 0.9998 \\
\hline $\mathbf{2 5}$ & 0.978 & $1.85 \mathrm{E}-04$ & 0.9999 \\
\hline $\mathbf{2 6}$ & 0.994 & $3.15 \mathrm{E}-05$ & $>0.999$ \\
\hline $\mathbf{2 7}$ & 0.965 & $3.41 \mathrm{E}-04$ & 0.9997 \\
\hline $\mathbf{2 8}$ & 0.998 & $1.84 \mathrm{E}-05$ & $>0.999$ \\
\hline $\mathbf{2 9}$ & 0.996 & $3.80 \mathrm{E}-05$ & $>0.999$ \\
\hline $\mathbf{3 0}$ & 1 & $1.52 \mathrm{E}-07$ & $>0.999$ \\
\hline $\mathbf{3 1}$ & 0.998 & $1.82 \mathrm{E}-05$ & $>0.999$ \\
\hline & & & \\
\hline
\end{tabular}


Table 7. Watershed scale values from the linear regression analysis of TP Yield.

\begin{tabular}{|c|c|c|c|}
\hline SW ID & Slope & Std. Error & $\mathbf{R}^{\mathbf{2}}$ \\
\hline $\mathbf{1}$ & 0.984 & $2.23 \mathrm{E}-04$ & 0.999 \\
\hline $\mathbf{2}$ & 0.979 & $2.64 \mathrm{E}-04$ & 0.9998 \\
\hline $\mathbf{3}$ & 0.989 & $1.51 \mathrm{E}-04$ & 0.9999 \\
\hline $\mathbf{4}$ & 0.986 & $1.78 \mathrm{E}-04$ & 0.9999 \\
\hline $\mathbf{5}$ & 0.998 & $2.87 \mathrm{E}-05$ & $>0.999$ \\
\hline $\mathbf{6}$ & 0.988 & $1.66 \mathrm{E}-04$ & 0.9999 \\
\hline $\mathbf{7}$ & 0.972 & $3.21 \mathrm{E}-04$ & 0.9997 \\
\hline $\mathbf{8}$ & 0.982 & $2.15 \mathrm{E}-04$ & 0.9999 \\
\hline $\mathbf{9}$ & 0.988 & $1.44 \mathrm{E}-04$ & 0.9999 \\
\hline $\mathbf{1 0}$ & 0.990 & $1.36 \mathrm{E}-04$ & $>0.999$ \\
\hline $\mathbf{1 1}$ & 0.966 & $2.20 \mathrm{E}-04$ & 0.9999 \\
\hline $\mathbf{1 2}$ & 0.942 & $2.94 \mathrm{E}-04$ & 0.9998 \\
\hline $\mathbf{1 3}$ & 0.972 & $1.07 \mathrm{E}-04$ & $>0.999$ \\
\hline $\mathbf{1 4}$ & 0.989 & $1.10 \mathrm{E}-04$ & $>0.999$ \\
\hline $\mathbf{1 5}$ & 0.980 & $1.53 \mathrm{E}-04$ & 0.9999 \\
\hline $\mathbf{1 6}$ & 0.987 & $1.44 \mathrm{E}-04$ & 0.9999 \\
\hline $\mathbf{1 7}$ & 0.999 & $7.14 \mathrm{E}-06$ & $>0.999$ \\
\hline $\mathbf{1 8}$ & 0.976 & $2.00 \mathrm{E}-04$ & 0.9999 \\
\hline $\mathbf{1 9}$ & 0.973 & $2.17 \mathrm{E}-04$ & 0.9999 \\
\hline $\mathbf{2 0}$ & 0.992 & $7.02 \mathrm{E}-05$ & $>0.999$ \\
\hline $\mathbf{2 1}$ & 0.962 & $2.24 \mathrm{E}-04$ & 0.9999 \\
\hline $\mathbf{2 2}$ & 0.974 & $3.07 \mathrm{E}-04$ & 0.9997 \\
\hline $\mathbf{2 3}$ & 0.957 & $2.37 \mathrm{E}-04$ & 0.9998 \\
\hline $\mathbf{2 4}$ & 0.987 & $2.49 \mathrm{E}-04$ & 0.9998 \\
\hline $\mathbf{2 5}$ & 0.979 & $1.50 \mathrm{E}-04$ & 0.9999 \\
\hline $\mathbf{2 6}$ & 0.994 & $2.70 \mathrm{E}-05$ & $>0.999$ \\
\hline $\mathbf{2 7}$ & 0.970 & $2.43 \mathrm{E}-04$ & 0.9998 \\
\hline $\mathbf{2 8}$ & 0.998 & $1.74 \mathrm{E}-05$ & $>0.999$ \\
\hline $\mathbf{2 9}$ & 0.997 & $3.83 \mathrm{E}-05$ & $>0.999$ \\
\hline $\mathbf{3 0}$ & 1 & $1.28 \mathrm{E}-07$ & $>0.999$ \\
\hline $\mathbf{3 1}$ & 0.998 & $1.65 \mathrm{E}-06$ & $>0.999$ \\
\hline & & & \\
\hline
\end{tabular}


Table 8. Subwatershed scale values from the linear regression analysis of TP Load.

\begin{tabular}{|c|c|c|c|}
\hline SW ID & Slope & Std. Error & $\mathbf{R}^{\mathbf{2}}$ \\
\hline $\mathbf{1}$ & 0.506 & $1.12 \mathrm{E}-03$ & 0.9876 \\
\hline $\mathbf{2}$ & 0.572 & $1.54 \mathrm{E}-03$ & 0.9819 \\
\hline $\mathbf{3}$ & 0.507 & $1.14 \mathrm{E}-03$ & 0.9873 \\
\hline $\mathbf{4}$ & 0.815 & $7.95 \mathrm{E}-04$ & 0.9976 \\
\hline $\mathbf{5}$ & 0.974 & $1.37 \mathrm{E}-04$ & 0.9999 \\
\hline $\mathbf{6}$ & 0.595 & $2.65 \mathrm{E}-03$ & 0.9519 \\
\hline $\mathbf{7}$ & 0.596 & $1.05 \mathrm{E}-03$ & 0.9921 \\
\hline $\mathbf{8}$ & 0.581 & $1.56 \mathrm{E}-03$ & 0.9818 \\
\hline $\mathbf{9}$ & 0.547 & $1.31 \mathrm{E}-03$ & 0.9856 \\
\hline $\mathbf{1 0}$ & 0.899 & $5.15 \mathrm{E}-04$ & 0.9992 \\
\hline $\mathbf{1 1}$ & 0.612 & $1.43 \mathrm{E}-03$ & 0.9862 \\
\hline $\mathbf{1 2}$ & 0.586 & $1.37 \mathrm{E}-03$ & 0.9863 \\
\hline $\mathbf{1 3}$ & 0.795 & $1.17 \mathrm{E}-03$ & 0.9945 \\
\hline $\mathbf{1 4}$ & 0.836 & $8.60 \mathrm{E}-04$ & 0.9973 \\
\hline $\mathbf{1 5}$ & 0.649 & $1.43 \mathrm{E}-03$ & 0.9878 \\
\hline $\mathbf{1 6}$ & 0.546 & $1.48 \mathrm{E}-03$ & 0.9816 \\
\hline $\mathbf{1 7}$ & 0.991 & $5.90 \mathrm{E}-05$ & $>0.999$ \\
\hline $\mathbf{1 8}$ & 0.911 & $6.87 \mathrm{E}-04$ & 0.9985 \\
\hline $\mathbf{1 9}$ & 0.895 & $9.39 \mathrm{E}-04$ & 0.9972 \\
\hline $\mathbf{2 0}$ & 0.977 & $1.88 \mathrm{E}-04$ & 0.9999 \\
\hline $\mathbf{2 1}$ & 0.635 & $1.16 \mathrm{E}-03$ & 0.9916 \\
\hline $\mathbf{2 2}$ & 0.853 & $1.30 \mathrm{E}-03$ & 0.9941 \\
\hline $\mathbf{2 3}$ & 0.595 & $1.13 \mathrm{E}-03$ & 0.9909 \\
\hline $\mathbf{2 4}$ & 0.980 & $3.87 \mathrm{E}-04$ & 0.9996 \\
\hline $\mathbf{2 5}$ & 0.928 & $4.91 \mathrm{E}-04$ & 0.9993 \\
\hline $\mathbf{2 6}$ & 0.991 & $4.20 \mathrm{E}-05$ & $>0.999$ \\
\hline $\mathbf{2 7}$ & 0.667 & $1.64 \mathrm{E}-03$ & 0.9848 \\
\hline $\mathbf{2 8}$ & 0.997 & $2.60 \mathrm{E}-05$ & $>0.999$ \\
\hline $\mathbf{2 9}$ & 0.988 & $1.19 \mathrm{E}-04$ & $>0.999$ \\
\hline $\mathbf{3 0}$ & 1 & $1.28 \mathrm{E}-07$ & $>0.999$ \\
\hline $\mathbf{3 1}$ & 0.998 & $1.65 \mathrm{E}-05$ & $>0.999$ \\
\hline & & & \\
\hline
\end{tabular}


Table 9. Subwatershed scale values from the linear regression analysis of TP Concentration.

\begin{tabular}{|c|c|c|c|}
\hline SW ID & Slope & Std. Error & $\mathbf{R}^{\mathbf{2}}$ \\
\hline $\mathbf{1}$ & 0.511 & $1.04 \mathrm{E}-03$ & 0.9896 \\
\hline $\mathbf{2}$ & 0.599 & $1.93 \mathrm{E}-03$ & 0.9741 \\
\hline $\mathbf{3}$ & 0.504 & $1.01 \mathrm{E}-03$ & 0.9899 \\
\hline $\mathbf{4}$ & 0.828 & $8.86 \mathrm{E}-04$ & 0.9971 \\
\hline $\mathbf{5}$ & 0.976 & $1.17 \mathrm{E}-04$ & 0.9999 \\
\hline $\mathbf{6}$ & 0.551 & $2.05 \mathrm{E}-03$ & 0.9659 \\
\hline $\mathbf{7}$ & 0.596 & $2.01 \mathrm{E}-03$ & 0.9719 \\
\hline $\mathbf{8}$ & 0.603 & $1.90 \mathrm{E}-03$ & 0.9753 \\
\hline $\mathbf{9}$ & 0.556 & $1.45 \mathrm{E}-03$ & 0.9829 \\
\hline $\mathbf{1 0}$ & 0.905 & $6.60 \mathrm{E}-04$ & 0.9986 \\
\hline $\mathbf{1 1}$ & 0.616 & $1.74 \mathrm{E}-03$ & 0.9799 \\
\hline $\mathbf{1 2}$ & 0.583 & $1.26 \mathrm{E}-03$ & 0.9883 \\
\hline $\mathbf{1 3}$ & 0.765 & $1.24 \mathrm{E}-03$ & 0.9934 \\
\hline $\mathbf{1 4}$ & 0.826 & $1.05 \mathrm{E}-03$ & 0.9959 \\
\hline $\mathbf{1 5}$ & 0.659 & $1.90 \mathrm{E}-03$ & 0.9792 \\
\hline $\mathbf{1 6}$ & 0.585 & $1.76 \mathrm{E}-03$ & 0.9775 \\
\hline $\mathbf{1 7}$ & 0.991 & $7.85 \mathrm{E}-05$ & $>0.999$ \\
\hline $\mathbf{1 8}$ & 0.896 & $9.78 \mathrm{E}-04$ & 0.997 \\
\hline $\mathbf{1 9}$ & 0.874 & $1.19 \mathrm{E}-03$ & 0.9953 \\
\hline $\mathbf{2 0}$ & 0.976 & $2.50 \mathrm{E}-04$ & 0.9998 \\
\hline $\mathbf{2 1}$ & 0.666 & $1.52 \mathrm{E}-03$ & 0.9869 \\
\hline $\mathbf{2 2}$ & 0.831 & $1.30 \mathrm{E}-03$ & 0.9938 \\
\hline $\mathbf{2 3}$ & 0.599 & $1.36 \mathrm{E}-03$ & 0.987 \\
\hline $\mathbf{2 4}$ & 0.978 & $4.87 \mathrm{E}-04$ & 0.9994 \\
\hline $\mathbf{2 5}$ & 0.928 & $6.05 \mathrm{E}-04$ & 0.9989 \\
\hline $\mathbf{2 6}$ & 0.991 & $5.11 \mathrm{E}-05$ & $>0.999$ \\
\hline $\mathbf{2 7}$ & 0.675 & $1.91 \mathrm{E}-03$ & 0.9801 \\
\hline $\mathbf{2 8}$ & 0.998 & $2.82 \mathrm{E}-05$ & $>0.999$ \\
\hline $\mathbf{2 9}$ & 0.987 & $1.15 \mathrm{E}-04$ & $>0.999$ \\
\hline $\mathbf{3 0}$ & 1 & $2.55 \mathrm{E}-07$ & $>0.999$ \\
\hline $\mathbf{3 1}$ & 0.998 & $1.82 \mathrm{E}-05$ & $>0.999$ \\
\hline & & & \\
\hline
\end{tabular}


Table 10. Subwatershed scale values from the linear regression analysis of TP Yield.

\begin{tabular}{|c|c|c|c|}
\hline SW ID & Slope & Std. Error & $\mathbf{R}^{\mathbf{2}}$ \\
\hline $\mathbf{1}$ & 0.506 & $1.12 \mathrm{E}-03$ & 0.9876 \\
\hline $\mathbf{2}$ & 0.572 & $1.54 \mathrm{E}-03$ & 0.9819 \\
\hline $\mathbf{3}$ & 0.507 & $1.14 \mathrm{E}-03$ & 0.9873 \\
\hline $\mathbf{4}$ & 0.815 & $7.95 \mathrm{E}-04$ & 0.9976 \\
\hline $\mathbf{5}$ & 0.974 & $1.37 \mathrm{E}-04$ & 0.9999 \\
\hline $\mathbf{6}$ & 0.595 & $2.65 \mathrm{E}-03$ & 0.9519 \\
\hline $\mathbf{7}$ & 0.596 & $1.05 \mathrm{E}-03$ & 0.9921 \\
\hline $\mathbf{8}$ & 0.581 & $1.56 \mathrm{E}-03$ & 0.9818 \\
\hline $\mathbf{9}$ & 0.547 & $1.31 \mathrm{E}-03$ & 0.9856 \\
\hline $\mathbf{1 0}$ & 0.899 & $5.15 \mathrm{E}-04$ & 0.9992 \\
\hline $\mathbf{1 1}$ & 0.612 & $1.43 \mathrm{E}-03$ & 0.9862 \\
\hline $\mathbf{1 2}$ & 0.586 & $1.37 \mathrm{E}-03$ & 0.9863 \\
\hline $\mathbf{1 3}$ & 0.795 & $1.17 \mathrm{E}-03$ & 0.9945 \\
\hline $\mathbf{1 4}$ & 0.836 & $8.60 \mathrm{E}-04$ & 0.9973 \\
\hline $\mathbf{1 5}$ & 0.649 & $1.43 \mathrm{E}-03$ & 0.9878 \\
\hline $\mathbf{1 6}$ & 0.546 & $1.48 \mathrm{E}-03$ & 0.9816 \\
\hline $\mathbf{1 7}$ & 0.991 & $5.90 \mathrm{E}-05$ & $>0.999$ \\
\hline $\mathbf{1 8}$ & 0.911 & $6.87 \mathrm{E}-04$ & 0.9985 \\
\hline $\mathbf{1 9}$ & 0.895 & $9.39 \mathrm{E}-04$ & 0.9972 \\
\hline $\mathbf{2 0}$ & 0.977 & $1.88 \mathrm{E}-04$ & 0.9999 \\
\hline $\mathbf{2 1}$ & 0.635 & $1.16 \mathrm{E}-03$ & 0.9916 \\
\hline $\mathbf{2 2}$ & 0.853 & $1.30 \mathrm{E}-03$ & 0.9941 \\
\hline $\mathbf{2 3}$ & 0.595 & $1.13 \mathrm{E}-03$ & 0.9909 \\
\hline $\mathbf{2 4}$ & 0.980 & $3.87 \mathrm{E}-04$ & 0.9996 \\
\hline $\mathbf{2 5}$ & 0.928 & $4.91 \mathrm{E}-04$ & 0.9993 \\
\hline $\mathbf{2 6}$ & 0.991 & $4.20 \mathrm{E}-05$ & $>0.999$ \\
\hline $\mathbf{2 7}$ & 0.667 & $1.64 \mathrm{E}-03$ & 0.9848 \\
\hline $\mathbf{2 8}$ & 0.997 & $2.60 \mathrm{E}-05$ & $>0.999$ \\
\hline $\mathbf{2 9}$ & 0.988 & $1.19 \mathrm{E}-04$ & $>0.999$ \\
\hline $\mathbf{3 0}$ & 1 & $1.28 \mathrm{E}-07$ & $>0.999$ \\
\hline $\mathbf{3 1}$ & 0.998 & $1.65 \mathrm{E}-06$ & $>0.999$ \\
\hline & & & \\
\hline
\end{tabular}

Subwatershed 30 consistently had the highest slope of 1, meaning that this watershed has the lowest impact on TP enrichment from its land management activities. Additionally, subwatersheds 17, 26, 28, 29 and 31 consistently had high slopes, suggesting the land use and management in those subwatersheds have little-to-no impact on TP levels in the watershed. Subwatersheds 1, 3, 9, 12, 16 and 23 consistently hold the lowest slope, suggesting the highest variation in TP from land use and management activities specific to the subwatershed. The standard error represents the average distance the observed data falls from the regression line. 
The subwatersheds with the highest standard error had the largest amount of variation in TP values for that specified subwatershed. The $\mathrm{R}^{2}$ value is another representation of how close the manipulated data fits the base data. The closer the $\mathrm{R}^{2}$ value is to 1 , the better the equation is at predicting base model outputs.

\subsection{Percent Reduction}

Figure 6 displays the results for percent TP reduction at the watershed scale for load concentration and yield, while Figure 7 displays the percent TP reduction at the subwatershed scale.

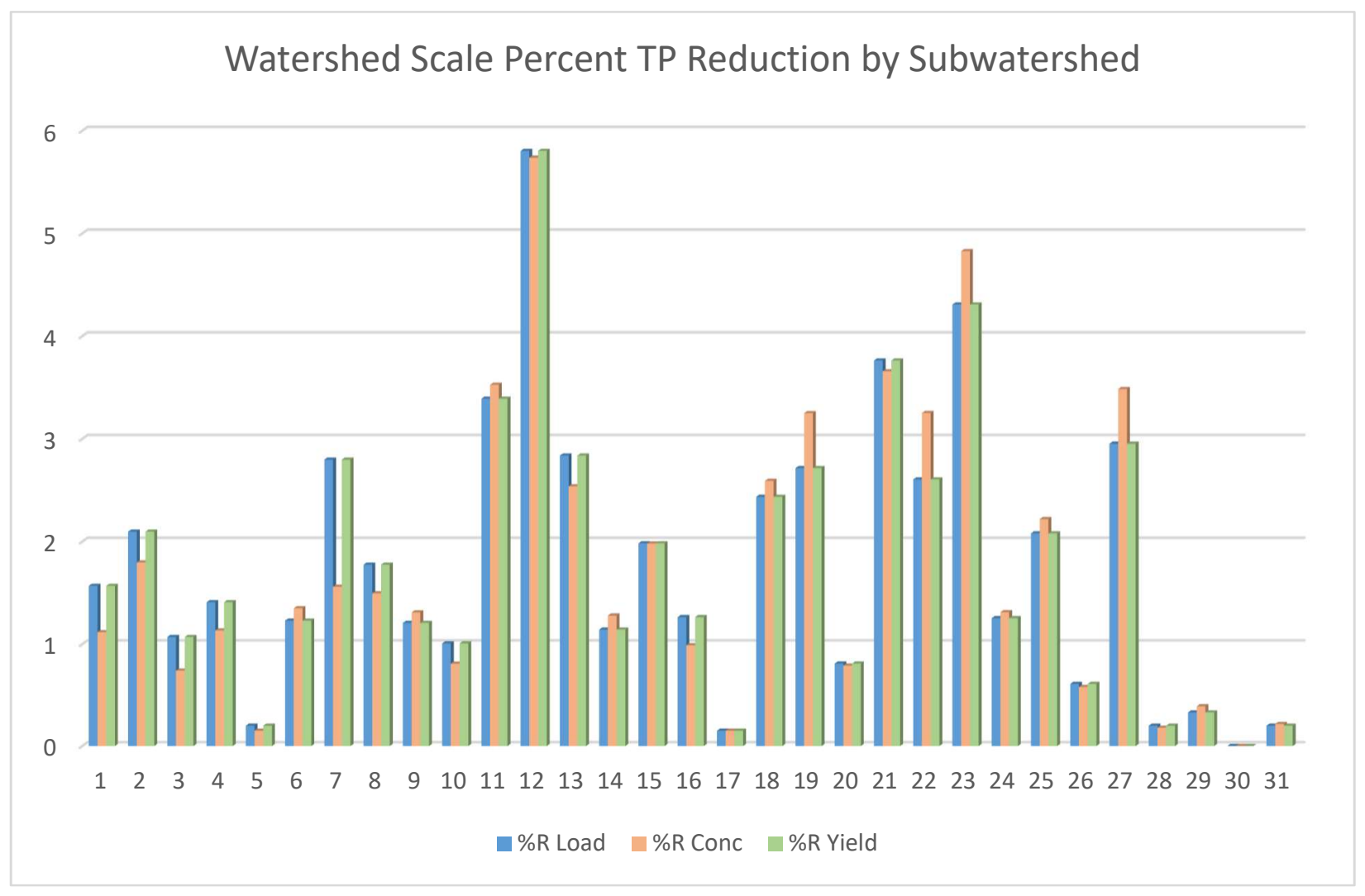

Figure 6. Watershed scale representation of a percent reduction in TP load, concentration and yield from 31 manipulated model runs to the base model. 


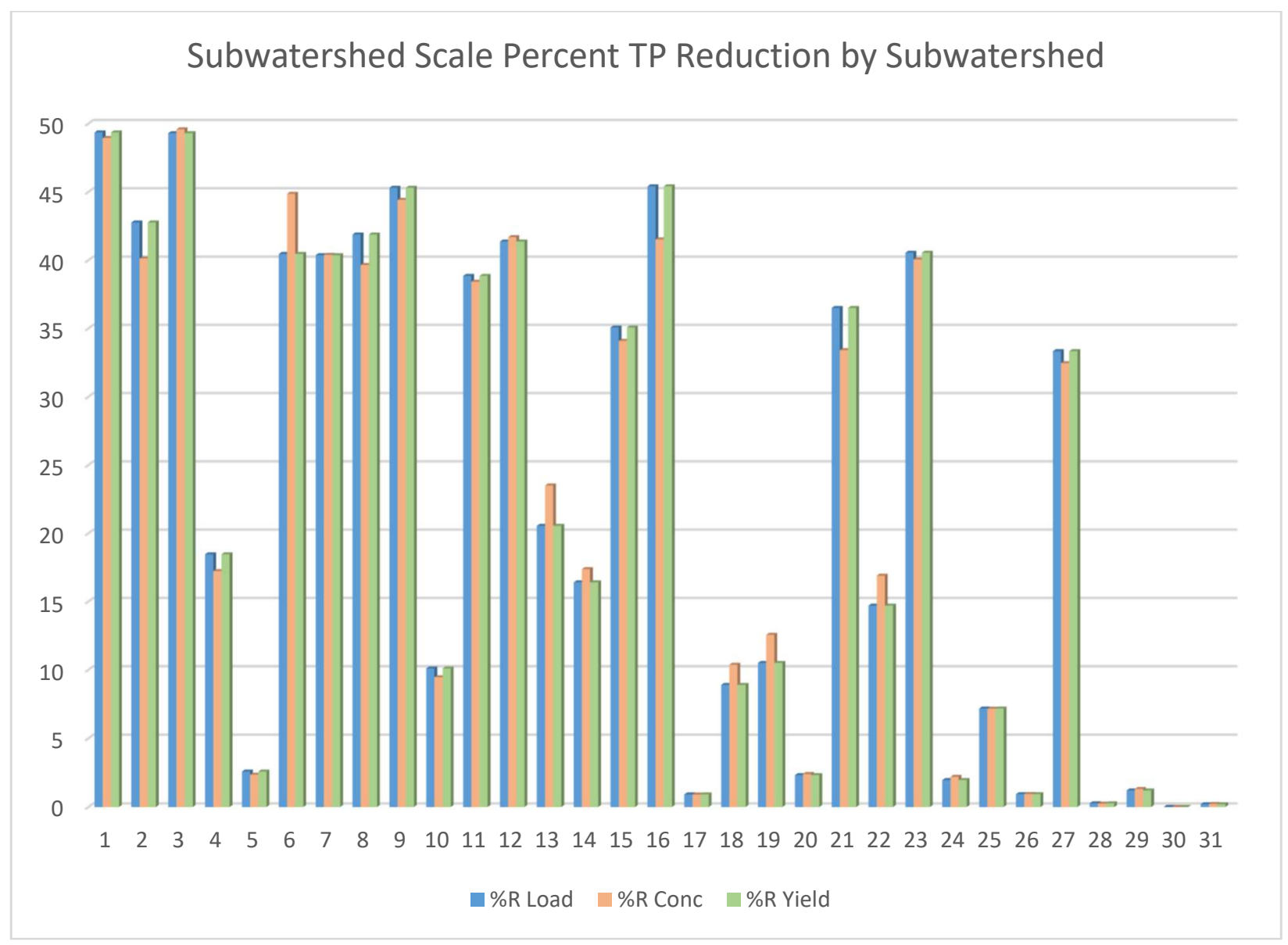

Figure 7. Subwatershed scale representation of a percent reduction in TP load, concentration and yield from 31 manipulated model runs to the base model.

\subsection{Linear Regression Output Analysis}

\subsubsection{Differences in subwatershed and watershed-scale reductions}

Due to the nature of the comparison, the results show much higher percent reduction in TP when looking at the outputs from the subwatershed scale. When looking at the watershed-scale, SW \#12 has the highest percent reduction but when looking at the subwatershed results, SW\# 1 and 3 have the highest percent reduction. The explanation for this discrepancy between the two scales is due to the size of the watershed. SW \#12 has an area of 3,335 hectares, while SW\#1 and 3 compose of 1,501 and 1,122 hectares respectively. When looking at the watershed-scale the area of SW\#12 has more influence on total reduction.

\subsubsection{Differences in load, concentration and yield}

Figures 6 and 7 display the differences in the linear regression outputs for load, concentration and yield in each of the subwatersheds, at both the watershed and subwatershed scale. The load and yield outputs at each of the subwatersheds are consistently equivalent while the 
concentration results show either a smaller or larger reduction. This can be explained as the load and yield are constants, load is an output of milligrams per day and yield is kilograms per hectare per day, with the area staying consistent through the ten years of model outputs. On the other hand, concentration depends on flows, expressed as milligrams per liter. The concentration values are dependent on the DMW-SWAT daily flow outputs, resulting in slightly higher or lower values for linear regression.

\subsubsection{Land use for top subwatersheds}

In the watersheds that are showing the highest reductions for TP load, concentration and yield, there is a trend in the classification of land use, with each watershed having a large percentage of forested lands. This dominant land use is closely followed by range or pasture lands, Table 11. The subwatersheds in the southern reaches of the watershed display a large agricultural influence in land use/land cover. This distribution of dominant land use, indicates that erosion and runoff events from forested and agricultural areas load phosphorus to the stream network.

Implementing monitoring locations that sample TP from these subwatersheds would help identify specific phosphorus sources and inform future mitigation and restoration efforts.

Table 11. Percent land use of subwatersheds with highest percent reduction in TP load, concentration and yield.

\begin{tabular}{|c|c|c|c|c|}
\hline $\begin{array}{c}\text { DMW-SWAT } \\
\text { ID }\end{array}$ & Forest & Range/Pasture & Residential & Agriculture \\
\hline $\mathbf{1}$ & 59.39 & 40.61 & 0.00 & 0.00 \\
$\mathbf{2}$ & 51.89 & 45.31 & 2.44 & 0.00 \\
$\mathbf{3}$ & 70.74 & 30.56 & 0.00 & 0.00 \\
$\mathbf{6}$ & 62.20 & 32.80 & 4.83 & 0.00 \\
$\mathbf{7}$ & 46.25 & 51.37 & 3.67 & 0.00 \\
$\mathbf{8}$ & 64.01 & 34.99 & 2.31 & 0.00 \\
$\mathbf{9}$ & 48.07 & 35.92 & 2.53 & 0.00 \\
$\mathbf{1 1}$ & 40.79 & 29.29 & 7.98 & 23.23 \\
$\mathbf{1 2}$ & 45.18 & 36.06 & 9.34 & 10.72 \\
$\mathbf{1 6}$ & 44.74 & 31.55 & 0.00 & 25.02 \\
$\mathbf{2 3}$ & 12.38 & 20.67 & 11.97 & 56.27 \\
\hline
\end{tabular}

\subsection{Proposed Monitoring: Location and Frequency}

3.4.1. Monitoring sites suggested from analysis. Subwatersheds with the highest percent reductions in load, concentration and yield show the highest variability from manipulation of ERORGP, which represents TP runoff during rainfall events Percent reductions of load, concentration and yield, based on linear regression data, were highest in subwatersheds 1, 2, 3, 6, $7,8,9,11,12,16$, and 23. TP. Thus, analysis suggests monitoring should occur in DMWSWAT subwatersheds $1,2,3,6,7,8,9,11,12,16$, and 23 . To continue the collection of long- 
term datasets, I recommend continuing to monitor water quality at the stations that are currently collecting data in the basin, located in DMW-SWAT subwatersheds 5, 24, 29 and 31.

Since some of these DMW-SWAT subwatersheds are located within close proximity to each other, their effect on water quality can be captured with one strategically placed monitoring location. I recommend stations in Table 12 for continued or future monitoring implementation.

Subwatersheds 1, 2, and 3 are located at the headwaters of East Fork Dairy Creek. Just downstream, there is a current station collecting data in DMW-SWAT subwatershed 5. Collecting data at this location would add to long-term data as well as capture the water quality response to land-use and management from subwatersheds 1, 2 and 3. Similarly, DMW-SWAT subwatersheds 11 and 16 are of close proximity and a single water quality monitoring location in subwatershed 16 will capture the water quality data from the land-use and management in these subwatersheds. Finally, DMW-SWAT watershed 23 is just upstream of the monitoring station located in subwatershed 29. Continuing to collect data at this station would add to the long-term data set as well as capture the water quality response to land-use and management in subwatershed 23. Figure 8 shows the location of the stations within the 31 SWAT-delineated subwatershed network.

Table 12. Dairy-McKay proposed monitoring locations. The DMW-SWAT ID denotes the subwatershed ID, chosen from analysis, that the monitoring location will be located. Any additional subwatershed ID's that the monitoring location will capture, also chosen based on results from analysis, are included in the parenthesis.

\begin{tabular}{lll}
\hline DMW-SWAT ID & Station ID & Description \\
\hline SUB 5* (1,2,3) & ORDEQ- 22457 & East Fork Dairy Creek near Meacham Corner \\
SUB 6/7 & ORDEQ- 22434 & West Fork Dairy Creek at Fisher Rd \\
SUB 8/9 & ORDEQ- 23124 & McKay Creek at Collins Rd \\
SUB 12 & ORDEQ- 10492 & West Fork Dairy Creek at Hwy 6 \\
SUB 16 (11) & ORDEQ- 10631 & East Fork Dairy Creek at Hwy 26 \\
SUB24* & ORDEQ- 11497 & Dairy Creek at Susbauer Road \\
SUB 29* (23) & ORDEQ- 22438 & McKay Creek at Padgett Road \\
SUB 31* & ORDEQ- 10491 & Dairy Creek at Oregon Route 8 \\
\hline
\end{tabular}

*Denotes current monitoring location. 
Figure 8. Proposed monitoring stations within the SWAT-delineated DMW Basin, with subwatershed identifications.

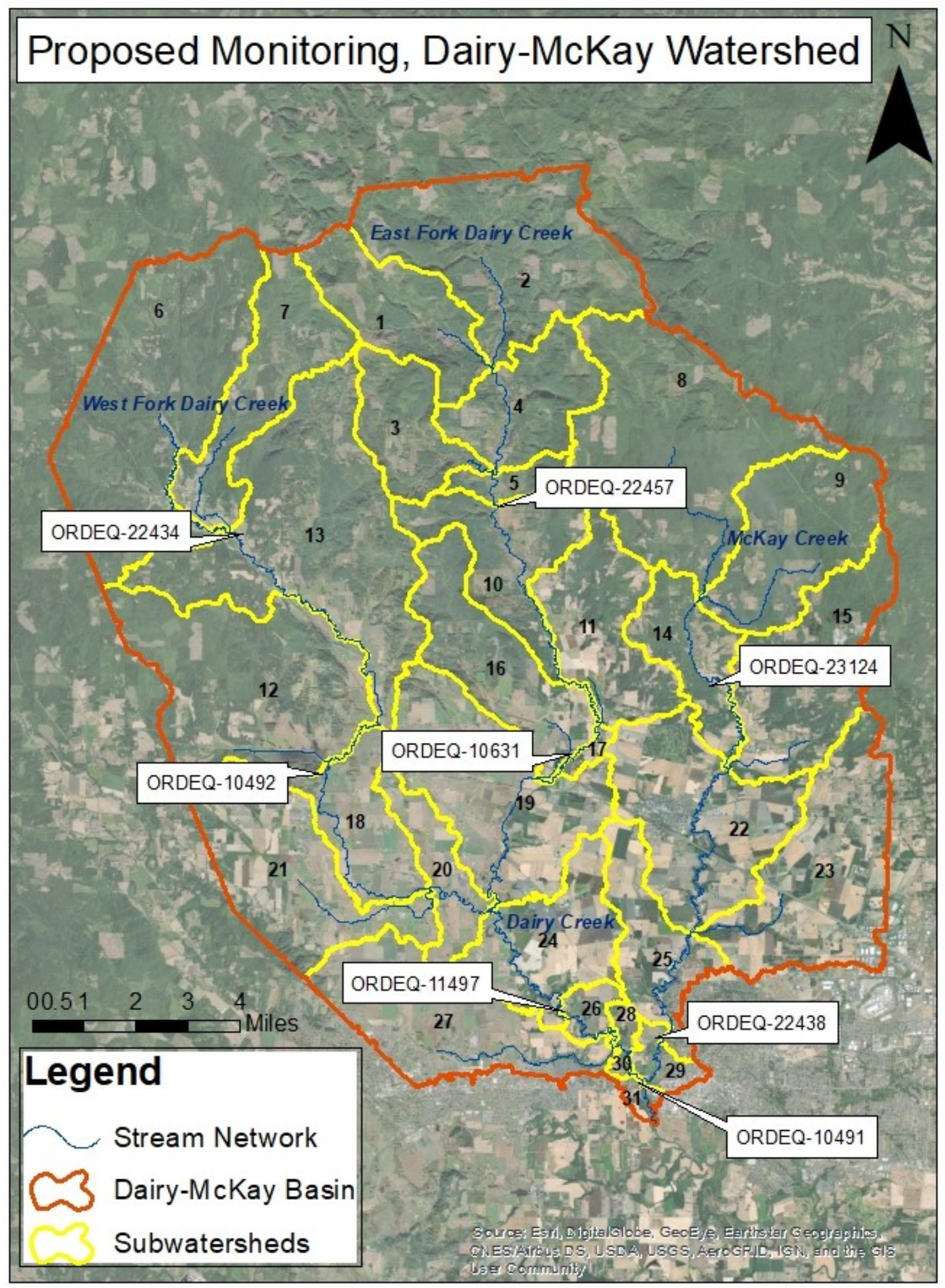


3.4.2. Proposed sampling and frequency. In attempts to have consistent data for future analysis, I propose that sampling at each location be uniform for both parameter and frequency. The DEQ laboratory currently collects phosphorus samples in accordance with Standard Method 4500, developed and updated by EPA. It is recommended that, at a minimum, 50-60 monthly samples be collected to show data trends with confidence (ODEQ Hillsboro Lab, 2005). This many samples would account for five years of monthly sampling, January-December, or less time with an increased frequency of collection. As current water quality monitoring sampling in the DMW occurs more frequently than monthly intervals, I would recommend taking uniform samples for future watershed-scale analysis.

Other parameters of concern for the CEP watershed assessment were not assessed in the model but would be important to monitor. These parameters include bacteria (E.coli), dissolved oxygen and temperature. These parameters also address TMDLs in the greater Tualatin River Watershed and are of importance for identifying trends. These parameters can be assessed simultaneously with phosphorus grab-samples.

The proposed monitoring stations (Figure 9) would improve understanding of water quality within the DMW. Based on analysis, subwatersheds 1, 2, 3, 9, and 16 display the most potential of influencing phosphorus loading from management activities. Therefore, monitoring at ORDEQ stations 22457, 23124 and 10631 are top priority. Collecting samples at all of the proposed monitoring locations would provide uniform water quality parameter monitoring throughout the watershed. Each of the Dairy Creek tributaries, West Fork, East Fork and McKay Creeks, would have a monitoring location about midway through the stream segments. These data will enhance the current understanding of water quality, as represented from the three current stations at the mouth of the DMW to the Tualatin River. Additional analysis of historic and incoming data can help to understand where the highest sources of TP occur within the DMW. In turn, analysis of incoming data will be beneficial for future BMP implementation, allowing for more accurate placement of practices to continue watershed-scale efforts aimed at improving of water quality within the DMW and the greater Tualatin. 
Figure 9. Map of proposed monitoring in the Dairy-McKay Watershed, based on results of linear regression analysis. Stations outline in red are currently collecting data, while stations outlined in green are new collection sites.

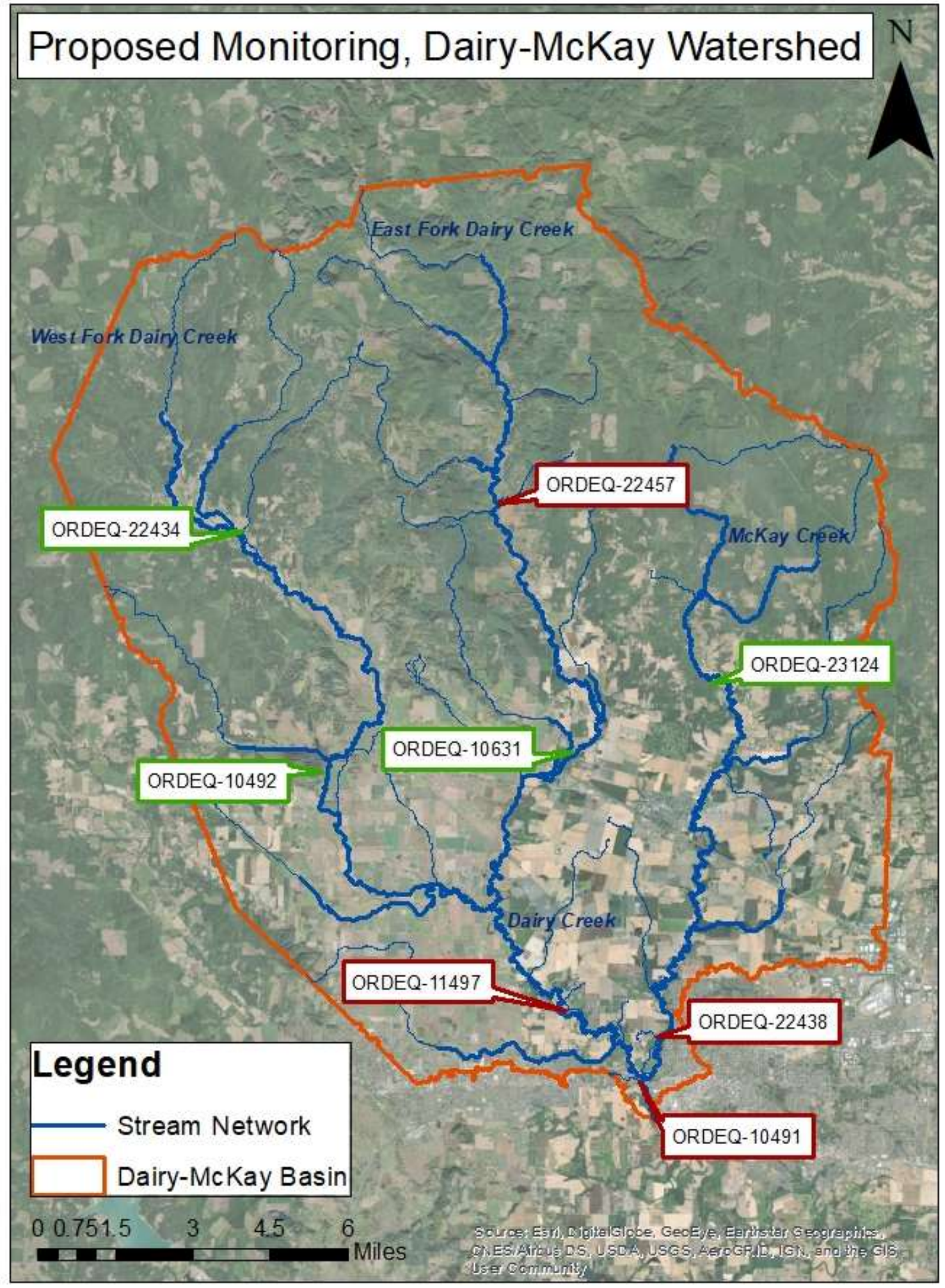


3.4.3. Additional flow monitoring. Utilizing current flow gage data, located within upper East Fork Dairy Creek, did not allow for successful model calibration. Daily flow data from this station provides flow for East Fork Dairy Creek, but does not give an accurate representation of flows in West Fork Dairy, McKay Creek or downstream of the confluence of Dairy Creek. For the future of SWAT modeling within the DMW, I suggest that the monitoring plan incorporate a flow gage at ORDEQ-10491, within DMW-SWAT subwatershed 30. Having flow data at this location would allow for increased efficiency of SWAT calibration attempts. As SWAT model outputs can occur at either daily, monthly or yearly instances, this sampling can occur at any of these time-intervals. For future modeling, I recommend that this data collection begins as soon as possible, reported consistently in either daily or monthly intervals. Immediate daily or monthly flow records will allow for enough data collection to complete calibration of the DMWSWAT model within a timely manner.

\subsection{Calibration Attempts}

For the physically based watershed model SWAT, calibration consists of manipulating model parameters that represent physiological processes in a way that model outputs have a close fit to known water quality data. Model calibration is conditional on numerous factors including: the type and amount of data used for calibration, the objective function definition, the hydrologic model, the optimization routine, and all other model assumptions (Abbaspour et al., 2015). Because of the time-consuming nature of manual trial-and-error model calibration, there has been a great deal of research into the development of automated, computer-based, calibration methods (Yapo et al., 1998). Due to time constraints as well as my novice understanding of model calibration, I employed the calibration software recommended by SWAT operators, SWAT-Calibration and Uncertainty Program (SWAT-CUP). SWAT-CUP is one of the new developments for calibration/sensitivity analysis of watershed models that incorporate a semiautomated approach Sequential Uncertainty Fitting (SUFI-2) which incorporates both manual and automatic calibration and global sensitivity analysis, assessing the sensitivity of input parameters (Khatun et al., 2018).

\subsection{Model Conditionality}

3.6.1. Data Limitations and Uncertainty. Observational data is simply a 'snapshot' of the real system, an instantaneous record of a few components from numerous complex and interactive processes that must be carefully interpreted (Arhonditsis and Brett, 2004). This can be true for agricultural watersheds, such as the DMW, in which the land ownership and crop grown is constantly changing. Land use, typically derived from aerial or satellite imaging, do not always hold 'ground-truth' or show changes over time in agricultural management, providing a snapshot of available data. Similarly, weather data inputs may not accurately represent conditions within the entire watershed. This can be seen in DMW-SWAT where one weather station was available to inform the model processes, while it is known that precipitation rates vary from the Tualatin 
Mountains to the Tualatin Plain. Uncertainty occurs in the extension of point data to large areas in distributed models (Abbaspour, 2015).

Data limitations can occur in the understanding of processes within the watershed. These can be processes that occur within the watershed, yet their occurrences in the watershed are unknown to the modeler or unaccountable (Abbaspour, 2015). An example of these processes can be seen on the farm management level in water rights and reservoir storage, water transfers, or irrigation rates. These processes occur throughout the watershed and may have a measurable effect on water quality, yet there may not be researched data available to the modeler or the processes may not be accessible for input to the modeling software. This can also occur due to limitation in the model framework, in which the processes that occur within a watershed are not modeled explicitly. For example, construction projects that occur within the watershed such as roads, tunnels bridges, etc. can change watershed flow and water quality for a number of years, depending on the project (Abbaspour, 2015). These projects may be known or unknown to the modeler yet there is not a way to readily, or accurately input the process to the model.

3.6.2. Challenges in Selecting and Modeling BMP. Although the DMW-SWAT model was used to simulate various BMPs, it is important to recognize that SWAT has limitations in simulating these processes. For example, filter strips are modeled at the HRU level and do not depict the true spatial relationships. Modeling this process at the HRU level means that each filter strip is actually modeled for all areas within a subwatershed with uniform land use, soils and slope as the original BMP point. If there are multiple filter strips within a subwatershed's HRU, the placement and effectiveness of the practice may vary, but there is no way capture this variability within the model. Finally, there is discrepancy in the true efficiency of the filter strip as there is no area input and filter strip length and width are completely dependent on the individual project.

Irrigation efficiency projects are included in RCPP funding and of interest to CEP, but were not modeled using SWAT software. Irrigation efficiencies are not readily input to SWAT as a conservation practice, but are applicable by coupling SWAT with APEX, the Agricultural Policy/Environmental eXtender Model (Waidler et al., 2009). The NRCS BMP database did not specify the irrigation efficiency applied or detail the water savings from the individual projects. Due to the lack of information of individual irrigation project descriptions from the NRCS BMP database, these conservation actions were not implemented to the model. Due to the small number of projects for irrigation efficiencies, CEP discussed measuring and tallying the savings of each project to account for total savings within the watershed. These data will be used for CEP assessment and reporting of project effectiveness and is not applicable to DMW-SWAT modeling efforts.

Of the dataset of BMPs provided by NRCS many were unable to be modeled due to their lack of available project-specific information. Projects that had no application date were not input to the model as there was no definitive answer as to if the database had not yet been updated or the practice had been abandoned due to a number of funding or landowner issues. Other practices, such as Wrote Nutrient Management Plan, did not provide any information on the plan. Simulation of nutrient management by uniformly reducing applied fertilizers may not provide useful or accurate information within model outputs. With no information on the reduction of 
nutrients, these plans were not modeled. Rather, this simulation in the DMW-SWAT model was based on information about soil nutrient status and crop nutrient requirements. 


\section{Conclusion}

In this study, a watershed-scale model of the Dairy-McKay Watershed was constructed using the SWAT program. Attempts to calibrate the model were unsuccessful, yet sensitivity of subwatersheds to phosphorus loading could still be conducted. Analysis was performed to see the effect of TP loading for 31 subwatersheds within the watershed. The results quantify the extent to which land use, specified land use management, as well as conservation actions might be able to affect NPS phosphorus loading. The subwatersheds with the highest analyzed variability are recommended for monitoring implementation as those subwatersheds were shown to be most sensitive to phosphorus loading from their distinctive land use and management. This model will be useful in the process of attaining water quality data, providing first steps towards identifying sources of phosphorus contamination within the basin.

The model could further be used to determine the most cost-effective means for meeting TMDL criteria. The current model results could not be readily used in decision making for the DMW because calibration of the SWAT-DMW simulation model has not been completed. The model is planned to have further development with incoming monitoring data. The scope of future analysis is to include: the effectiveness of conservation efforts at a watershed scale; identification of degraded stream segments that are most beneficial for BMP implementation; as well as costeffective analysis of conservation practices to limit phosphorus levels at the mouth of the watershed. 


\section{References:}

1. Abbaspour, K.C., Rouholahnejad, E., Vaghefi, S., Srinivasan, R., Yang, H., and Klove, B. A continental-scale hydrology and water quality model for Europe: Calibration and uncertainty of a high-resolution large-scale SWAT model. Journal of Hydrology. May 2015. Vol. 524, pp. 733-752.

2. Abbaspour, K.C., Yang, J., Maximov, I., Siber, R., Bogner, K., Mieleitner, J., Zobrist, J., and Srinivasan, R. Modelling hydrology and water quality in the pre-alpine/alpine Thur watershed using SWAT. Journal of Hydrology. February 15, 2007. Vol. 333 (2-4), pp. 413-430.

3. Abbaspour, Karim C. SWAT-CUP: SWAT Calibration and Uncertainty Programs, User Manual. EAWAG Aquatic Research. 2015. https://swat.tamu.edu/software/swat-cup/

4. Allan, J.D. and Costillo M.M. Stream Ecology: Structure and Function of Running Waters. Freshwater Biology. August 12, 2008. Vol. 53(9), pp. 436.

5. AMBROSE, R. B., T. A. WOOL, AND C. D. KNIGHTES. WASP TRANSPORT MODELING AND WASP ECOLOGICAL MODELING. Presented at NATO Programme Security Through Science, Dalyan, TURKEY. December 04 - 16, 2005.

6. Appleyard, V. and Williams, H. Beneficial Use of Watersheds. Journal of American Water Works Association. July 1970, Vol. 62 (7), pp. 455-457. https://www.jstor.org/stable/41265997

7. Arhonditsis, G.B. and Brett, M.T. Evaluation of the current state of mechanistic aquatic biogeochemical modeling. Marine Ecology Progress Series. April 28, 2004. Vol. 271, pp. 13-26.

8. Arnold, J.G., R. Srinivasan, R.S. Muttiah, and J.R. Williams. 1998. Large area hydrologic modeling and assessment part I: model development. J. American Water Resources Association 34 (1): 73-89.

9. Bekele, E.G. and Nicklow J.W. Multi-objective management of ecosystem services by integrative watershed modeling and evolutionary algorithms. Journal of Water Resources Research. October 12, 2005. Vol. 41(10), pp. 1-10. https://doi.org/10.1029/2005WR004090

10. BLM (Bureau of Land Management), United States Department of the Interior. 1999. Dairy-McKay Watershed Analysis. Prepared by BLM partnership with Washington County Soil and Water Conservation District, March 1999. Salem, OR.

11. Chapra, S.C. Surface water-quality modeling. Long Grove, III: Waveland Press. Published: 1997, Updated: 2008.

12. Chiang, L., Chaubey, I., Gitau, M., and Arnold, J. Differentiating Impacts of Land Use Changes from Pasture Management in a CEAP Watershed Using the SWAT Model. Transactions of ASABE. September 1, 2010. Volume 53.

13. Clean Water Services (CWS). Flow Management Annual Reports. Updated: 2017, Accessed: August 28, 2018. https://www.co.washington.or.us/Watermaster/SurfaceWater/tualatin-river-flow-technicalcommittee-annual-report.cfm

14. DeAngelis, Donald L. Integration of ecosystem theories: A pattern. Ecological Economics, Elsevier. April 1994. Vol. 9(3), pp. 276-277.

15. EPA. Basic Information about Nonpoint Source (NPS) Pollution. Updated: August 10, 2018. Retrieved: October 9, 2018. https://www.epa.gov/

16. EPA. Summary of the Clean Water Act. Updated: March 29, 2018. Retrieved: November 1, 2018. https://www.epa.gov/ 
17. Fraga, F.J., et al. A novel modeling framework to prioritize estimation of non-point source pollution parameters for quantifying pollutant origin and discharge in urban catchments. February 1, 2016. Journal of Environmental Management, Vol. 167, pp. 75-84. https://www-sciencedirectcom.proxy.lib.pdx.edu/science/article/pii/S0301479715303571

18. Franks, P.J.S. Coupled physical-biological models in oceanography. Reviews of Geophysics. 1995. Vol. 33, pp.1177-1187.

19. Fu, B., Liu, H.B., Lu, Y. et al. Study of the characteristics of nitrogen and phosphorus emission in the typical agricultural small watershed of Plateau Lake: A case study of Feng Yu River Watershed. Journal of Environmental Science. 2015. Vol. 35(9), pp. 29822899.

20. Gaston, Christian. Coho Salmon Flock to the Tualatin River. Forest Grove News. November 23, 2010. https://pamplinmedia.com/component/content/article?id=40412

21. Huang, J., Huang, Y., Pontius Jr., R.G. and Zhang, Z. Geographically weighted regression to measure spatial variation in correlations between water pollution versus land use in coastal watersheds. Ocean Coastal Management. 2015. Vol. 103, pp. 14-24.

22. Johanson, R., J. Imhoff, J. Kittle, Jr., A. Donigian. Updated: April 16, 2004. HYDROLOGICAL SIMULATION PROGRAM-FORTRAN (HSPF): USERS MANUAL FOR RELEASE 8.0. U.S. Environmental Protection Agency, Washington, D.C., EPA/600/3-84/066.

23. Khatun, S., Sahana, M., Jain, S.K., and Jain N. Simulation of surface runoff using semidistributed hydrological model for a part of Satluj Basin: parameterization and global sensitivity analysis using SWAT-CUP. Modeling Earth Systems and Environment. May 26, 2018. Vol. 4 (3), pp. 1111-1124.

24. Li, E. A., Shanholtz, V. O., Contractor, D. N., \& Carr, J. C. (1977). Generating rainfall excess based on readily determinable soil and land use characteristics. Trans. ASAE, 20(6), 1070-1078. http://dx.doi.org/10.13031/2013.35705.

25. Neitsch, S.L., J.G. Arnold, J.R. Kiniry and J.R. Williams. 2001. Soil and Water Assessment Tool User's Manual, Version 2000.

26. Orr, Elizabeth L., William N. Orr, and Ewart M. Baldwin. 1992. Geology of Oregon. 4th ed. Kendall/Hunt, Dubuque, Iowa.

27. ODEQ. Oregon Department of Environmental Quality. Tualatin Subbasin TMDL, Chapter 2: pH and Chlorophyll a TMDL Amendment. August 2012. https://www.oregon.gov/deq/FilterDocs/tualatinCh2Phosphorus.pdf

28. ODEQ. Oregon Department of Environmental Quality, Laboratory Division, Watershed Assessment Section. A Strategy for Monitoring Oregon's Waters. September 2005. https://www.oregon.gov/deq/FilterDocs/WaterMonitoringStrategyFinal.pdf

29. ODEQ. Oregon Department of Environmental Quality, with submissions from Oregon Dept. of Forestry, Oregon Dept. of Agriculture, Unified Sewerage Agency, City of Portland, City of West Linn, City of Lake Oswego, Multnomah County, Clackamas County, and Washington County. Appendix I, Tualatin River Subbasin Water Quality Management Plan. August 2001. https://www.oregon.gov/deq/FilterDocs/tmdlappxi.pdf

30. ODEQ. Oregon Department of Environmental Quality. Total Maximum Daily Loads. Accessed: November 1, 2018. www.oregon.gov/deq/wq/tmdls

31. Ouyang, Wei, et al. Long-term agricultural non-point source pollution loading dynamics and correlation with outlet sediment geochemistry. September 2016. Journal of 
Hydrology, Vol. 540, pp. 379-385. https://www-sciencedirect-

com.proxy.lib.pdx.edu/science/article/pii/S002216941630405X

32. Schlegel, Aaron. "Linear Regression through the Origin." Linear Regression through the Origin. 4 Jan. 2018. www.aaronschlegel.com/linear-regression-through-the-origin/

33. Soil Survey Staff, Natural Resources Conservation Service, United States Department of Agriculture. SSURGO. Web Soil Survey. Available online at https:/datagateway.nrcs.usda.gov/. Accessed: 4/23/2018.

34. Singh, G., Saraswat, D., and Sharply, Andrew. A Sensitivity Analysis of Impacts of Conservation Practices on Water Quality in L'Anguille River Watershed, Arkansas. Water. April 8, 2018. Vol. 10, Issue 4, pp. 443. https://doi.org/10.3390/w10040443

35. Smith, A.P., Western, A.W., and Hannah, M.C. Linking water quality trends with land use intensification in dairy farming catchments. Journal of Hydrology. 2013. Vol. 476, pp. 1-12.

36. Sun, B., Zhang, L.X., Yang, L.Z., Zhang, F., Norse, D., and Zhu, Z. Agricultural nonpoint source pollution in China: Causes and mitigation measures. Ambio. 2012. Vol. 41, pp. 370-379.

37. SWAT Theoretical Documentation. Available online: https://swat.tamu.edu/media/99192/swat2009-theory.pdf. Accessed: January 2018.

38. TAC (Tualatin Basin Technical Advisory Committee). 1997. Technical review of nonpoint sources of phosphorus and total maximum daily loads for tributaries of the Tualatin Basin. Report prepared by the nonpoint source subcommittee, May 1997. Hillsboro, OR.

39. Townsend, Lacey. TSWCD. Know Your Watershed. Accessed: August, 2018. https://www.swcd.net/education/schools/know-your-watershed/

40. Tualatin Soil and Water Conservation District, TSWCD. Irrigation Efficiency Financial Assistance. Accessed: November 2017. https://www.swcd.net/rural/irrigation/rcppirrigation/

41. United States Geological Survey (USGS), 2016, National Water Information System data available on the World Wide Web (USGS Water Data for the Nation), accessed May 10, 2018. http://dx.doi.org/10.5066/F7P55KJN

42. US EPA (2019). BASINS 4.5 (Better Assessment Science Integrating point \& Non-point Sources) Modeling Framework. National Exposure Research Laboratory, RTP, North Carolina. https://www.epa.gov/sites/production/files/201903/documents/basins4.5coremanual.2019.03.pdf

43. Vymazal, Jan and Březinová, Tereza. The use of constructed wetlands for removal of pesticides from agricultural runoff and drainage: A review. Environment International. February 2015. Vol. 75, pp. 11-20.

44. Waidler, D., White, M., Steglich, E., Wang, S., Williams, J., Jones, C.A., and Srinivasan, R. Conservation Practice Modeling Guide for SWAT and APEX. August 2009. https://swat.tamu.edu/media/57882/Conservation-Practice-Modeling-Guide.pdf

45. Winchell, M., Srinivasan, R., Di Luzio, J., and Arnold, J. ArcSWAT Interface for SWAT 2012 [Computer software]. March 2013.Temple, TX: Blackland Research and Extension Center.

46. Wolf, D.W. 1992. Land use and nonpoint source phosphorus pollution in the Tualatin Basin, Oregon: A literature review. Tualatin River Basin Water Resources Management 
Report Number 1. Published by Water Resources Research Institute and Oregon State University Extension Service. Corvallis, OR.

47. Yapo, P.O., Gupta, H.V. and Sorooshian, S. Multi-objective global optimization for hydrologic model. Journal of Hydrology. August 28, 1997. Vol. 204, pp. 83-97.

48. Zhou, P., Huang, J., Pontius, R.G., and Hong, H. New insight into the correlations between land use and water quality in a coastal watershed of China: Does point source pollution weaken it? Science of the Total Environment. February 2016. Vol. 543, pp. 591-600. https://doi.org/10.1016/j.scitotenv.2015.11.063. 